\title{
Uppgjör afleiðusamninga: Mat á reglum út frá dómafordæmum
}

\author{
Arnar Davíð Arngrímsson, Hersir Sigurgeirsson og Jakob Már \\ Ásmundsson ${ }^{1}$
}

\begin{abstract}
Ágrip
Alpjóðlegar reglur og venjur um framkvæmd afleiðusamninga hafa í gegnum tíðina mótast af dómafordæmum. Saga afleiðusamninga á Íslandi er stutt og framan af komu ekki mörg deilumál til kasta dómstóla. Petta breyttist í kjölfar bankahrunsins árið 2008 pegar fjölmörg ágreiningsefni vegna afleiðusamninga rötuðu fyrir dómstóla. Í greininni er farið yfir helstu dóma, sem fjalla um uppgjör afleiðusamninga, með pað аð markmiði að draga fram pær reglur og leiðbeiningar sem íslenskir dómstólar hafa gefið um uppgjör slíkra samninga undanfarin ár. Reifaðar eru niðurstöður 35 hæstaréttardóma.

Ágreiningsefnum aðila er skipt í sjö flokka: (1) heimildir til afleiðuviðskipta, (2) gengisviðmiðun gjaldmiðlasamninga, (3) reiknireglur við uppgjör, (4) forsendubrestur, (5) skuldajöfnun, (6) viðbrögð bankanna við yfirtöku Fjármálaeftirlitsins og (7) áhrif af yfirtöku Fjármálaeftirlitsins.

Meðal helstu niðurstaðna er að öllum er heimilt samkvæmt lögum að gera afleiðusamninga og framvirkir samningar um hlutabréf teljast ekki flóknir fjármálagerningar. Miða skal við viðmiðunargengi Seðlabanka Íslands í uppgjöri gjaldmiðlasamninga ef annað viðmið er ekki sérstaklega tiltekið og samningur, sem verður til við framlengingu á eldri samningi, telst nýr sjálfstæður samningur.

Fjallað er um áhrif yfirtöku Fjármálaeftirlitsins á bönkunum á stöðu afleiðusamninga og viðbrögð bankanna við yfirtökunni gagnvart viðskiptavinum með opna afleiðusamninga. Viðbrögðin voru mismunandi en Landsbanki Íslands og Glitnir ákváðu að senda viðskiptavinum sínum tilkynningu varðandi lokun samninganna. Tilkynning Landsbanka Íslands pótti óljós og túlka purfti pýðingu hennar út frá viðbrögðum hvers viðskiptavinar sem leiddi til mismunandi meðferðar einstakra viðskiptavina.
\end{abstract}

\begin{abstract}
Practices and regulation in international derivatives markets have historically been significantly influenced by legal precedents. The Icelandic derivatives market is relatively young and legal precedents were few and far between until the collapse of the banking system in 2008, which gave rise to a myriad of legal disputes having to do with the settlement of derivative contracts. The purpose of this article is to

1 Arnar Davíð Arngrímsson er meistaranemi við hagfræðideild Háskóla Íslands. Netfang: ada23@hi.is. Hersir Sigurgeirsson er dósent við viðskiptafræðideild Háskóla Íslands og í bankaráði Landsbankans. Netfang: hersir@hi.is. Jakob Már Ásmundsson er lektor við viðskiptafræðideild Háskóla Íslands. Netfang:
\end{abstract} jma@hi.is

This work is licensed under a Creative Commons Attribution 4.0 License.

DOI: https://doi.org/10.24122/tve.a.2018.15.1.1 
review the key findings of the Icelandic courts in this regard and attempt to identify some guiding principles. A review of 35 Supreme Court rulings is covered.

The disputes are divided into seven categories: (1) permissions to engage in derivative transactions, (2) reference rate for foreign exchange, (3) calculation methods, (4) force majeure, (5) netting of payments, (6) reaction to the intervention of the Financial Supervisory Authority (FSA), and (7) impact of FSA intervention.

Among some of the key findings is that everyone is entitled to engage in derivative contracts and that forward contracts on stocks are not considered a complex financial instrument. The foreign exchange rate of the Icelandic Krona, as determined by the Central Bank of Iceland, should be used for reference in settlement of derivatives if another reference is not explicitly stated. A derivatives contract that has been rolled, constitutes a new contract.

The intervention of the FSA in taking over individual banks and its impact on the settlement of outstanding derivatives contracts for respective banks is reviewed, including the impact of how individual banks communicated with their counterparties. The conduct of individual banks towards their counterparties differed, which impacted the settlement. Landsbanki and Glitnir both sent their clients announcements informing that outstanding derivatives contracts would be closed. However, the wording in the case of Landsbanki was somewhat unclear and had to be interpreted in the context of how individual clients responded, resulting in varying methods being applied to individual clients.

JEL flokkun: K12, K22, G01, G21, G23.

Lykilorð: Afleiður; afleiðusamningar; uppgjör afleiðusamninga; vanefnd; slitameðferð banka.

Keywords: Derivatives; default; bank liquidation.

\section{Settlement of derivative contracts: Principles from legal precedents}

\section{Inngangur}

Pegar íslensku viðskiptabankarnir féllu haustið 2008 voru peir aðilar að umfangsmiklum afleiðusamningum við viðskiptavini sína. Í árslok 2007 nam nafnvirði útistandandi afleiðusamninga bankanna priggja á samstæðugrundvelli rúmlega 15 púsund milljörðum króna, sem var ellefuföld verg landsframleiðsla pess árs, og hafði aukist um helming frá pví árið áður. ${ }^{2}$ Mótaðilar bankanna í afleiðuviðskiptunum voru allt frá einstaklingum og stórum sem smáum fyrirtækjum til lífeyrissjóða og alpjóðlegra banka.

Pessi markaður nær purrkaðist út við fall bankanna árið 2008 en á undanförnum árum hefur afleiðusamningum aftur tekið að fjölga. Markaðurinn er pó enn langt frá pví sem hann var á árunum fyrir hrun en í lok árs 2017 var nafnvirði afleiðusamninga íslensku bankanna um 850 milljarðar króna eða priðjungur af vergri landsframleiðslu. Á tímabilinu 2006-2017 voru gjaldeyris- og vaxtaafleiður algengustu afleiðusamningar bankanna. Gjaldeyrisafleiður voru umfangsmestar par til fyrir tveimur árum en pá jókst vægi vaxtaafleiðna umfram gjaldeyrisafleiður. Nafnvirði vaxtaafleiðna bankanna nam í lok árs 2017 tæpum 520 milljörðum króna en nafnvirði gjaldeyrisafleiðna um 300 milljörðum króna.

Pegar bönkunum var skipt upp í nýja og gamla banka voru afleiðusamningar peirra skildir eftir í gömlu bönkunum par sem ekki var talið að nýju bankarnir gætu staðið við

2 Upplýsingar um umfang afleiðuviðskipta íslensku viðskiptabankanna eru fengnar úr samstæðuársreikningum Glitnis, Kauppings og Landsbanka Íslands á árunum 2006 og 2007 og Arion banka, Landsbankans og Íslandsbanka á árunum 2008-2017. Hluti afleiðusamninga gömlu bankanna var í erlendum dótturfélögum bankanna svo að fjárhæðirnar endurspegla ekki einungis afleiðuviðskipti íslenskra aðila á árunum 2006-2007. Pá leiðir pessi aðferð til einhvers ofmats á umfangi afleiðusamninga par sem hugsanlegir afleiðusamningar milli bankanna priggja eru settir fram í ársreikningum tveggja peirra og eru pví tvítaldir. 
pær skuldbindingar sem í peim fólust. Við pað purftu gömlu bankarnir og mótaðilar peirra að ná niðurstöðu um uppgjör samninganna. Fjölmörg ágreiningsefni komu upp milli aðila um uppgjörið og endaði sá ágreiningur í mörgum tilvikum fyrir dómstólum. Hæstiréttur hefur pegar fellt dóm í a.m.k. 35 málum tengdum afleiðuviðskiptum bankanna og pví liggur fyrir niðurstaða um fjölmörg ágreiningsefni. Grein sem pessi getur pó aldrei verið tæmandi og pegar hún er rituð bíða enn nokkur ágreiningsmál úrlausnar fyrir dómstólum.

Meginmarkmiðið með ritun pessarar greinar er að draga fram pær reglur og leiðbeiningar sem íslenskir dómstólar hafa gefið um uppgjör afleiðusamninga. Á alpjóðavettvangi hafa reglur og venjur um framkvæmd afleiðusamninga í gegnum tíðina oft orðið til í kjölfar dómafordæma. Fyrir bankahrun höfðu ekki mörg deilumál vegna slíkra samninga komið til kasta íslenskra dómstóla en í kjölfar bankahrunsins fjölgaði málum verulega. Í ljósi mikillar fjölgunar afleiðusamninga á undanförnum árum er mikilvægt fyrir bæði banka og viðskiptavini peirra að hafa í huga hvaða fordæmi Hæstiréttur hefur gefið varðandi gerð og uppgjör peirra.

Í pessari grein er farið yfir helstu ágreiningsefni aðila í pessum málum og niðurstöðu Hæstaréttar varðandi pau. Ágreiningsefnunum er skipt í sjö flokka: (1) heimildir til afleiðuviðskipta, (2) gengisviðmiðun gjaldmiðlasamninga, (3) reiknireglur við uppgjör, (4) forsendubrestur, (5) skuldajöfnun, (6) viðbrögð bankanna við yfirtöku Fjármálaeftirlitsins og (7) áhrif af yfirtöku Fjármálaeftirlitsins. Greinin er pannig upp byggð аð í hverjum kaflanna 2-8 er fjallað um sérhvern flokk ágreiningsefnanna og að lokum eru helstu niðurstöður greinarinnar teknar saman í kafla 9. Lista yfir pá dóma, sem reifaðir eru í greininni, er að finna í kafla 10.

\subsection{Skilmálar afleiðusamninga á íslenskum markaði}

Engin íslensk lög fjalla eingöngu um afleiðusamninga pó að peirra sé getið í einstökum lögum. Ef ekki er kveðið sérstaklega á um annað í afleiðusamningi gilda pví sömu lög um slíka samninga og aðra samninga. Ef samningur aðila tiltekur ekki hvernig taka skuli á tilteknu atriði getur pví purft að beita meginreglum laga eða lögum sem ekki voru sérstaklega samin með afleiðusamninga í huga til að leysa úr ágreiningi aðila.

Vegna sérstöðu afleiðusamninga og peirra fyrirsjáanlegu ágreiningsefna, sem upp geta komið vegna peirra, hafa flestir peir aðilar, sem gera slíka samninga, sett fram skilmála sem gilda um pá og teljast hluti af hverjum samningi. Við upphaf viðskiptasambands undirrita samningsaðilar skilmálana og sampykkja að peir gildi um öll afleiðuviðskipti peirra í milli nema annað sé tekið fram í einstökum samningum. Í afleiðuviðskiptum íslenskra aðila hafa einkum prjár tegundir skilmála gilt: (1) ISDA-skilmálar, (2) SFF-skilmálar og (3) skilmálar einstakra banka. Er nánar fjallað um hverja tegund skilmála hér á eftir. I slíkum skilmálum er til dæmis að finna skilgreiningar á hugtökum sem notuð eru í afleiðusamningum, upplýsingar um almenn réttindi og skyldur samningsaðila, um hvað teljist vanefnd á samningi og hvernig uppgjöri milli aðila skuli háttað eftir vanefnd. Skilmálarnir eru hins vegar misýtarlegir og misjafnt getur verið milli skilmála hvað telst vanefnd og hvernig uppgjöri skuli háttað eftir vanefnd. Á petta hefur reynt í íslenskri dómaframkvæmd og hefur niðurstaða dómstóla oft oltið á pví hvaða skilmálar giltu um samninga aðila.

\subsubsection{ISDA-skilmálar}

Alpjóðasamtök um skiptasamninga og afleiður, The International Swaps and Derivatives Association eða ISDA, eru samtök sem voru stofnuð árið $1985^{3}$ með pað að markmiði að gera afleiðumarkaði á heimsvísu skilvirkari og öruggari. Meðal pess sem ISDA hefur gert til að stuðla að pessum markmiðum er að útbúa staðlaða samninga og skilmála um

3 Pegar samtökin voru stofnuð hétu pau The International Swap Dealers' Association en nafni peirra var breytt árið 1993. 
afleiðuviðskipti. ISDA-skilmálarnir gilda yfirleitt í afleiðuviðskiptum milli banka og í viðskiptum banka við stærri fyrirtæki og stofnanir.

Fyrirkomulag skilmálanna er með peim hætti að einn rammasamningur (e. master agreement) er almenns eðlis og gildir um öll afleiðuviðskipti milli samningsaðila. Við rammasamninginn eru gerðar viðbætur (e. schedules), sem eru hugsaðar til að sérsníða skilmálana að samningsaðilum, og auk peirra viðauki vegna trygginga (e. credit support annex) og staðfestingar (e. confirmations) vegna einstakra samninga. Ef rammasamningur og viðbætur stangast á pá víkur rammasamningurinn (ISDA, e.d.; ISDA, 2002). ISDA-skilmálarnir eru mjög ýtarlegir og nákvæmir og til dæmis eru skilgreindir sjö atburðir, sem teljast vanefnd, og fimm atburðir sem teljast sjálfkrafa uppsögn samninga. Undir hverjum lið eru svo allt að níu undirliðir sem skilgreina atburðina nánar og nær skilgreiningin á vanefnd og sjálfkrafa uppsögn í heild yfir prjár blaðsíður.

\subsubsection{SFF-skilmálar}

Árið 1998 gáfu Samband íslenskra viðskiptabanka og Samband íslenskra sparisjóða (SÍSP) út leiðbeiningar fyrir framvirka samninga með gjaldmiðla og skiptasamninga með vexti og gjaldmiðla. Leiðbeiningarnar voru gefnar út vegna pess að slíkum samningum hafði fjölgað á árunum á undan og í peim voru settir fram almennir skilmálar fyrir slíka samninga. Fyrir útgáfu leiðbeininganna var nokkur munur á pví milli banka og sparisjóða hversu ýtarlegir skilmálar slíkra samninga voru og einnig gat pað verið breytilegt innan sömu fyrirtækja. Pessu fylgdi nokkuð óhagræði sem ætlunin var að bæta úr með almennum skilmálum.

Skilmálarnir gilda um alla afleiðusamninga milli aðila sem hafa gengist undir pá. Peir víkja pó ef misræmi er milli peirra og samningsskilmála einstakra samninga (Samband íslenskra viðskiptabanka og Samband íslenskra sparisjóða, 1998). Skilmálarnir taka á flestum peim atriðum sem huga parf að við gerð afleiðusamninga en peir eru ekki nándar nærri eins ýtarlegir eða nákvæmir og ISDA-skilmálarnir. Sem dæmi eru tilgreindir fjórir atburðir sem teljast vanefnd og er skilgreiningin á vanefnd í heild sett fram á tæpri blaðsíðu.

Samband íslenskra viðskiptabanka rann inn í Samtök banka og verðbréfafyrirtækja við stofnun peirra samtaka í desember árið 2000 og í upphafi árs 2007 sameinuðust pau Sambandi íslenskra tryggingafélaga í Samtökum fjármálafyrirtækja (SFF) sem aðildarfélög SÍSP urðu jafnframt aðilar að. Eftir pað voru skilmálarnir oftast nefndir SFF-skilmálar og er pað heiti notað hér eftir.

\subsubsection{Skilmálar einstakra banka}

Íslenskir bankar eru með sína eigin skilmála sem viðskiptavinir purfa að sampykkja vilji peir stunda verðbréfaviðskipti við pá. Pessir skilmálar eru samdir einhliða af bönkunum og bera pess skýrt merki. Í skilmálunum er nánast eingöngu kveðið á um rétt bankanna gagnvart viðskiptavinunum en mun minna um réttindi viðskiptavinar gagnvart bönkunum (sjá t.d. Arion banki, 2012).

\subsubsection{Mál nr. 253/2012, Arnar Sigurðsson gegn SPB hf.}

Arnar Sigurðsson gerði skiptasamning við SPB (áður Sparisjóðabanki Íslands hf.) par sem viðmiðunarbréfin voru annars vegar ríkisskuldabréf, sem bankinn átti að fá greidda hækkun af, og hins vegar skuldabréf útgefin af Exista hf. sem viðskiptavinurinn átti að fá greidda hækkun af. SPB hélt pví fram að í samningnum fælist einnig að ef skuldabréf Exista lækkaði í verði ætti viðskiptavinurinn að greiða lækkunina. Vegna pessa keypti SPB skuldabréfið til að verja sig. Viðskiptavinurinn taldi að aðeins hefði verið samið um að hann myndi njóta hækkana af viðmunarbréfum en pyrfti ekki að bera skaða af lækkunum.

Í dómi Hæstaréttar sagði að skilmálar samningsins hafi verið mótsagnarkenndir en par sagði m.a. „Viðskiptamanni ber að greiða pær hækkanir sem kunna að verða á markaðs- 
virði viðmiðunarbréfa viðskiptamanns frá samningsdegi miðað við markaðsgengi pað sem bankinn býður á gjalddaga, en til frádráttar koma pær lækkanir sem kunna að verða á markaðsvirði viðmiðunarbréfa viðskiptamanns.“ Að mati dómsins felst í pessu pversögn pannig að greinin verður markleysa. Skilmálarnir eru samdir einhliða af SPB og sagði Hæstiréttur að gera mætti kröfu um að fjármálafyrirtæki sýndi vandvirkni og aðgæslu gagnvart viðskiptavinum sínum. Pví var pað niðurstaða Hæstaréttar að SPB skyldi bera hallann af pessu atriði.

Eins og niðurstaða í pessu máli ber með sér er mikilvægt að skilmálar séu skýrir. Pegar skilmálar, sem eru samdir einhliða af banka, eru í gildi er líklegt að vafamál, sem upp kunna að koma, verði túlkuð viðskiptavininum í hag.

\section{Heimildir til afleiðuviðskipta}

Fyrsta ágreiningsefnið, sem hér er fjallað um, er hverjir hafi heimild til að stunda afleiðuviðskipti. Pví hefur verið haldið fram að með gildistöku nýrra laga um verðbréfaviðskipti árið 2007 hafi almennum fjárfestum verið bannað að eiga í viðskiptum með flókna fjármálagerninga og að afleiður falli par undir. Aðilar, sem jafnvel hafa stundað afleiðuviðskipti í áraraðir, hafa m.a. haldið pví fram að peir hafi ekki haft næga pekkingu á peim viðskiptum sem peir stunduðu. Að peirra mati bar bankanum, sem peir voru í viðskiptum við, að upplýsa pá betur um eðli peirra viðskipta, sem peir voru að stunda, og gæta pess að viðskiptin hentuðu peirra reynslu og markmiðum.

\subsection{Helstu lagaákvæði}

Hinn 1. nóvember 2007 tóku gildi ný lög um verðbréfaviðskipti nr. 108/2007, sem komu í stað eldri laga nr. 33/2003. Með lögunum var innleidd svokölluð MiFID-tilskipun Evrópusambandsins (e. Markets in Financial Instruments Directive). Markmiðið með tilskipuninni, og par með lögunum, var að setja samræmdar reglur í Evrópu um neytendavernd fjárfesta. Helstu kröfum MiFID-tilskipunarinnar má skipta í prennt (Fjármálaeftirlitið, 2008):

- Fjármálafyrirtæki komi fram af heiðarleika, sanngirni og fagmennsku gagnvart viðskiptavinum sínum.

- Fjármálafyrirtæki veiti ýtarlegar upplýsingar sem eru skýrar, ekki villandi og viðeigandi fyrir viðskiptavininn.

- Fjármálafyrirtæki veiti viðskiptavinum sínum pjónustu miðað við aðstæður hvers og eins.

Fjármálafyrirtækjum er skylt samkvæmt lögunum að flokka væntanlega viðskiptavini sína í almenna fjárfesta, fagfjárfesta og viðurkennda gagnaðila og njóta viðskiptavinir mismikillar neytendaverndar á grundvelli pess hvernig peir eru flokkaðir. Mestrar verndar njóta almennir fjárfestar, síðan fagfjárfestar og minnstu verndar njóta viðurkenndir gagnaðilar. Skilgreining á fagfjárfesti er á pá leið að hann skuli búa yfir „reynslu, pekkingu og sérfræðikunnáttu“ til að meta áhættu og taka sjálfstæðar ákvarðanir um fjárfestingar. Viðurkenndur gagnaðili er t.d. ríkisstjórn, sveitarfélag, seðlabanki eða stór alpjóðleg stofnun. Almennur fjárfestir er skilgreindur sem fjárfestir sem er ekki fagfjárfestir eða viðurkenndur gagnaðili.

Neytendaverndin í lögunum felst m.a. í strangari kröfum en áður til fjármálafyrirtækja um öflun upplýsinga um tilvonandi viðskiptavini og um pá ráðgjöf og upplýsingar sem fjármálafyrirtækjum ber að veita viðskiptavinum sínum. Samkvæmt 16. gr. laganna skulu fjármálafyrirtæki leita eftir upplýsingum um reynslu og pekkingu viðskiptavinar á viðkomandi verðbréfaviðskiptum til að geta metið hvort pau séu viðeigandi fyrir hann. Pó eru taldar upp nokkrar undanpágur frá pessu ákvæði og par á meðal eru tilteknir einfaldir fjármálagerningar. 
Skilgreiningu á fjármálagerningum er að finna í 2. gr. laganna en par segir m.a. (d-liður 2. tl. 1. mgr.): „Valréttarsamningar, framtíðarsamningar, skiptasamningar, framvirkir vaxtasamningar og aðrar afleiður sem byggjast á verðbréfum, gjaldmiðlum, vöxtum, ávöxtunarkröfu, öðrum afleiðum, fjárhagslegum vísitölum eða fjárhagslegum viðmiðum sem gera má upp efnislega eða með reiðufé.“ Samkvæmt pessu falla afleiður undir skilgreininguna á fjármálagerningum.

Skilgreining á pví hvað telst einfaldur fjármálagerningur samkvæmt lögum, og fellur par með undir fyrrnefndar undanpágur í 16. gr. laga nr. 108/2007, er að finna í 38. gr. reglugerðar nr. 995/2007. Par kemur fram að fjármálagerningur teljist einfaldur ef hann uppfyllir eftirfarandi skilyrði:

- Fjármálagerningurinn fellur ekki undir tilteknar skilgreiningar í 3. tl. 2. gr. laga nr. 108/2007. Dæmi um skilgreiningar undir peirri grein eru: „,verðbréf sem veita rétt til að kaupa eða selja verðbréf eða leiða til uppgjörs í reiðufé sem ræðst af verðbréfum, gjaldmiðlum, vöxtum eða ávöxtunarkröfum, hrávörum eða öðrum vísitölum eða mælikvörðum".

- Auðvelt er að selja fjármálagerninginn á verði, sem er opinbert og aðgengilegt fyrir markaðsaðila, eða ráðstafa gerningnum á annan hátt.

- Skuldbinding pess sem á fjármálagerninginn er takmörkuð við kaup á gerningnum.

- Upplýsingar um fjármálagerninginn eru opinberar og ýtarlegar pannig að almennur viðskiptavinur getur kynnt sér gerninginn og tekið upplýsta ákvörðun um hvort hann vilji eiga viðskipti með hann.

Par sem undirliggjandi breyta í afleiðusamningum er yfirleitt einhver peirra breyta, sem taldar eru upp í 3. tl. 2. gr. laga nr. 108/2007, mætti álykta að afleiður almennt féllu undir 3. tl. Pví myndu nánast engar afleiður falla undir undanpáguna í 16 gr. varðandi skyldu fjármálafyrirtækja til að leita upplýsinga um tilvonandi viðskiptavini. Pó ber að hafa í huga orðalag greinarinnar par sem talað er um að verðbréfin veiti rétt til að kaupa eða selja önnur verðbréf. Samkvæmt skilgreiningum á afleiðutegundum eru pað aðeins valréttir sem veita kaupendum peirra rétt til að kaupa eða selja undirliggjandi eign. Aðrar afleiður kveða á um skilyrðislausa skyldu samningsaðila til að kaupa eða selja undirliggjandi eignir á tilgreindum tíma.

Í lögunum er einnig lögð sú skylda á fjármálafyrirtæki að hafa hag viðskiptavinar að leiðarljósi. Fjallað er um bestu framkvæmd í lögunum en í 18. gr. kemur fram að „fjármálafyrirtæki skuli leita allra leiða til að tryggja bestu mögulegu niðurstöðu fyrir viðskiptavini sína" en jafnframt að fjármálafyrirtækið skuli fara að fyrirmælum viðskiptavinarins ef hann fer fram á ákveðna framkvæmd. Fjármálafyrirtækjum er einnig skylt að starfa í samræmi við góða viðskiptavenju og „með trúverðugleika fjármálamarkaðarins og hagsmuni viðskiptavina að leiðarljósi“.

\subsection{Dómar Hæstaréttar}

\subsubsection{Mál nr. 631/2012, Byggingarhúsið ehf. gegn LBI hf.}

LBI, gamli Landsbankinn, stefndi Byggingarhúsinu vegna vanefnda á framvirkum samningi um hlutabréfakaup. Byggingarhúsið var flokkað sem almennur fjárfestir af Landsbankanum og hélt Byggingarhúsið pví fram að samningarnir væru flóknir fjármálagerningar sem væru gríðarlega áhættusamir. Vegna pessa hefði Landsbankanum borið að afla sér upplýsinga um viðskiptavininn og veita honum ráðgjöf í samræmi við pær upplýsingar en рað hefði hann ekki gert.

Hæstiréttur taldi ekki liggja fyrir að bankinn hefði uppfyllt að fullu skyldu sína um öflun upplýsinga um viðkomandi viðskiptavin og fjárfestingarmarkmið hans pannig að hann gæti veitt honum ráðgjöf í samræmi við hans aðstæður. Aftur á móti hafði fulltrúi viðskiptavinarins undirritað almenna markaðsskilmála bankans par sem hann staðfesti 
að hann hefði kynnt sér eðli slíkra samninga og myndi leita sér sérfræðiaðstoðar utan bankans ef hann teldi pörf á pví. Viðskiptavininum hefði pví átt að vera ljós sú áhætta sem fólst í samningunum. Pá leit Hæstiréttur einnig til pess að viðskiptavinurinn hafði stundað sams konar viðskipti um nokkurt skeið. Dómurinn komst að peirri niðurstöðu að jafnvel pótt bankinn hefði ekki að öllu leyti farið eftir pví sem lögin kveða á um varðandi upplýsingaöflun og ráðgjöf pá væru engar heimildir í lögunum til að ógilda samningana. Pá komst dómurinn einnig að peirri niðurstöðu í málinu að framvirkir samningar um hlutabréfakaup teljist ekki til flókinna fjármálagerninga enda er áhættan af peim sú sama og ef um er að ræða kaup á hlutabréfum sem fjármögnuð eru með lántöku.

\subsubsection{Mál nr. 630/2012, Byggingarhúsið ehf. gegn LBI hf.}

Í málinu voru sömu málsaðilar og í máli nr. 631/2012 (sjá 2.2.1) en undirliggjandi hlutabréf voru önnur. Niðurstaða Hæstaréttar var sú sama.

\subsubsection{Mál nr. 509/2013, Einar Pétursson gegn LBI hf.}

Einar Pétursson hafði gert framvirka samninga við gamla Landsbankann um kaup á hlutabréfum í Exista hf. Hlutabréfin lækkuðu verulega í verði í kjölfar bankahrunsins. Einar hélt pví fram að bankinn hefði brugðist skyldum sínum samkvæmt lögum um verðbréfaviðskipti og að Einar hefði ekki notið peirrar verndar sem honum bar sem almennum fjárfesti.

Hæstiréttur komst að peirri niðurstöðu að ekki hefði verið sýnt fram á að bankinn hefði brugðist skyldu sinni samkvæmt lögum um verðbréfaviðskipti. Í dómnum kemur fram að nýju lögin um verðbréfaviðskipti leggi ekki „,bann við pví að almennir fjárfestar stundi afleiðuviðskipti“. Strangari fyrirmæli séu pó um form samninga, upplýsingaöflun um viðskiptavini, mat á hæfni peirra og um ráðleggingar til peirra við upphaf viðskiptasambands eða við breytingu á pví. Hæstiréttur vísaði til athugasemda við lagafrumvarpið par sem kemur fram að pau ákvæði laganna, sem hin aukna skylda um upplýsingaöflun og veitingu upplýsinga til viðskiptavina byggir á, eigi einungis við um nýja viðskiptavini eða pegar stofnað er til nýrra tegunda viðskipta. Einar hafði átt í sams konar viðskiptum við Landsbankann og deilt var um í málinu samfellt frá árinu 2005 og pví hafi upplýsingaskylda Landsbankans gagnvart honum ekki verið eins rík og ef um nýjan viðskiptavin hefði verið að ræða. Pá var vísað til framangreinds dóms í máli nr. 631/2012 (sjá 2.2.1) varðandi pað að framvirkir samningar eins og pessir teljist ekki til flókinna fjármálagerninga.

Niðurstaðan byggir einnig á pví að Einar hafi undirritað markaðsskilmála Landsbankans og hafi haft pó nokkra reynslu af gerð svipaðra samninga en hann hafði gert 149 samninga um framvirk hlutabréfakaup við Landsbankann frá árinu 2005. Hæstiréttur benti einnig á að jafnvel pótt Einar hefði getað sýnt fram á að Landsbankinn hefði brugðist skyldum sínum samkvæmt lögum um verðbréfaviðskipti pá væri engin heimild til ógildingar á samningunum í peim lögum.

\subsubsection{Mál nr. 493/2013, Bjarni Már Bjarnason gegn LBI hf.}

Deilt var um heimild almennra fjárfesta til að stunda afleiðuviðskipti og komst Hæstiréttur að sömu niðurstöðu og í framangreindu máli nr. 509/2013 (sjá 2.2.3). Samkvæmt dómnum er ekkert í lögunum sem bannar almennum fjárfestum að stunda afleiðuviðskipti auk pess sem ekki pótti sýnt fram á að bankinn hefði brugðist skyldum sínum varðandi veitingu upplýsinga. Pá hafði viðskiptavinurinn skrifað undir almenna skilmála bankans par sem hann staðfesti að hann gerði sér grein fyrir peirri áhættu sem fylgdi samningunum.

\subsubsection{Mál nr. 638/2010, Landsbanki Íslands hf. gegn Njálu ehf.}

Landsbanki Îslands (gamli Landsbankinn) áfrýjaði dómi héraðsdóms í máli sem Njála hafði höfðað gegn bankanum. Njála höfðaði upphaflega málið á peim grundvelli að félagið hefði ranglega verið flokkað sem fagfjárfestir án pess að uppfylla pau skilyrði sem lögin 
kveða á um að fagfjárfestir purfi að uppfylla. Njála hafði sótt um að fá flokkun fagfjárfestis en pað var skilyrði fyrir pví að félagið gæti verið í virkri gjaldeyrisstýringu og stöðutöku hjá Landsbankanum.

Til að fá flokkun sem fagfjárfestir purfti að uppfylla a.m.k. tvö af premur skilyrðum sem tilgreind eru í 1. mgr. 24. gr. laga um verðbréfaviðskipti. Eitt skilyrðanna var að virði verðbréfaeignar viðskiptavinar nemi a.m.k. 46,2 milljónum króna. Í umsókn sinni tiltók Njála annars vegar virði verðbréfaeignar félagsins og enginn ágreiningur var um að félagið uppfyllti pað lágmarksskilyrði. Hins vegar tiltók félagið reynslu af verðbréfaviðskiptum. Umsækjandi parf að lágmarki að hafi gegnt stöðu á fjármálamarkaði í a.m.k. eitt ár og viðkomandi parf einnig að greina frá pví hvar hann gegndi stöðunni. Njála skrifaði „Landsbankinn“ í umsókn sinni en enginn af forsvarsmönnum félagsins hafði gegnt slíku starfi hjá Landsbankanum. Aftur á móti hafði Landsbankanum verið veitt umboð til að taka ákvarðanir varðandi stofnun og lokun afleiðusamninga fyrir hönd félagsins.

Hæstiréttur taldi reynslu og sérpekkingu starfsmanna Landsbankans ekki geta komið í stað slíkrar pekkingar hjá viðskiptavininum. Pví var pað mat Hæstaréttar að Landsbankanum hefði ekki verið heimilt að flokka pennan viðskiptavin sem fagfjárfesti. Af peim sökum hafði bankinn ekki veitt viðskiptavininum fullnægjandi upplýsingar til pess að hann gæti tekið upplýsta ákvörðun í samræmi við pað sem lög nr. 108/2007 gera ráð fyrir. Efnislega komst Hæstiréttur að sömu niðurstöðu og héraðsdómur sem hafði fellt skuldbindingu Njálu samkvæmt samningunum niður. Рað gerði héraðsdómur á grundvelli pess að bankinn hefði ekki fylgt lögunum varðandi flokkun fjárfesta og upplýsingagjöf til peirra ásamt pví að hafa trúverðugleika fjármálamarkaðarins að leiðarljósi. Að mati Hæstaréttar er hins vegar enga heimild að finna í lögunum til að ógilda samningana, jafnvel pótt fjármálafyrirtæki bregðist skyldum sínum gagnvart viðskiptavinum sínum samkvæmt lögunum. Hæstiréttur tók ekki undir pau rök Njálu að um hefði verið að ræða forsendubrest par sem dómurinn taldi flokkun viðskiptavinar ekki forsendu fyrir viðskiptunum prátt fyrir að fram hefði komið í máli fyrrverandi starfsmanns Landsbankans fyrir héraðsdómi að flokkun sem fagfjárfestir væri forsenda pess að viðskiptavinir gætu verið í virkri gjaldeyrisstýringu og stöðutöku. Í málinu krafðist Njála ekki skaðabóta vegna samninganna heldur hélt félagið pví fram að peir væru ógildir og krafðist endurgreiðslu vegna handveðs sem Landsbankinn hafði gengið að. Eins og áður segir féllst Hæstiréttur ekki á að samningarnir væru ógildir og hafnaði pví kröfu Njálu.

\subsubsection{Mál nr. 668/2014, Gunnar Magnússon gegn Dróma hf.}

Málavextir voru peir að Gunnar Magnússon hafði gert gjaldmiðlaskiptasamning við Frjálsa fjárfestingarbankann sem síðar var sameinaður Dróma hf. og tap varð af samningnum. Gunnar bar pví við að bankinn hefði ekki mátt gera við sig afleiðusamning par sem hann væri almennur fjárfestir og að bankinn hefði einnig brugðist upplýsingaskyldu sinni.

Hæstiréttur komst að sömu niðurstöðu og áður að ekkert ákvæði væri í lögum sem bannaði almennum fjárfestum að stunda afleiðuviðskipti. Auk pess vitnaði dómurinn til framangreinds dóms í máli nr. 638/2010 (sjá 2.2.5) par sem kemur fram að engin ógildingarákvæði séu í lögum um verðbréfaviðskipti pó að bankar bregðist skyldum sínum um flokkun viðskiptavina og upplýsingaskyldu sinni gagnvart peim.

\subsubsection{Mál nr. 184/2012, NVN ehf. og Einar Örn Jónsson gegn Landsbanka Íslands hf.}

NVN og Landsbanki Îslands (gamli Landsbankinn) höfðu gert með sér framvirkan samning um kaup NVN á hlutabréfum í bankanum. Meðal pess sem deilt var um í málinu var hvort Landsbankinn hefði veitt NVN fullnægjandi upplýsingar í samræmi við lög um verðbréfaviðskipti. Málsaðilar höfðu átt í viðskiptum með framvirka samninga a.m.k. frá árinu 2006 pegar NVN tók yfir aðild að premur framvirkum samningum sem Einar hafði gert við Landsbankann.

Við gildistöku laga nr. 108/2007 var fjármálafyrirtækjum skylt að flokka viðskiptavini 
sína. Landsbankinn sendi NVN bréf pess efnis að félagið væri flokkað sem fagfjárfestir og pað staðfesti Einar Örn fyrir hönd NVN. Prátt fyrir pað hélt NVN pví fram fyrir dómi að Landsbankanum hefði verið óheimilt að flokka félagið sem fagfjárfesti án pess að pað hefði óskað sérstaklega eftir pví.

Héraðsdómur byggði á framangreindum dómi Hæstaréttar í máli nr. 638/2010 (sjá 2.2.5) pegar hann komst að peirri niðurstöðu að engin ákvæði væru í lögum um ógildingu samninga á grundvelli rangrar flokkunar fjárfesta. Að mati Hæstaréttar var pó ekki hægt að vísa eingöngu til dómsins par sem málsaðstæður voru ólíkar. Í máli nr. 638/2010 hafði viðskiptavinurinn óskað eftir pví að vera flokkaður sem fagfjárfestir en í máli NVN var pað ákvörðun bankans að flokka NVN sem fagfjárfesti án pess að fyrir lægi ósk um pað frá viðskiptavininum auk pess sem félagið uppfyllti ekki skilyrði flokkunar sem fagfjárfestir. Atvik málsins varðandi pennan lið voru að mati Hæstaréttar vanreifuð og taldi hann ekki rétt að fella efnisdóm varðandi hann.

\subsubsection{Mál nr. 553/2015, Glitnir hf. gegn Porsteini Hjaltested}

Porsteinn Hjaltested hafði gert samning um eignastýringu við Glitni samkvæmt ákveðinni fjárfestingarstefnu. Porsteinn var flokkaður sem almennur fjárfestir af Glitni. Í málinu var deilt um fjórar fjárfestingar sem einkabankapjónustan fór í fyrir hönd Porsteins.

Hæstiréttur taldi mögulegan rétt Porsteins gagnvart Glitni hafa fallið niður vegna tómlætis vegna tveggja fjárfestinganna. Fram kemur í niðurstöðu Hæstaréttar að samkvæmt meginreglum fjármunaréttar geti samningsaðili glatað rétti sínum „til að bera fyrir sig vanefnd eða annað réttarbrot" ef ekki eru gerðar athugasemdir við slíkt án ástæðulauss dráttar. Jafnframt var eftirfarandi getið í athugasemd með frumvarpi að lögum nr. 33/2003:

að tómlæti geti haft meiri áhrif á réttarstöðu samningsaðila í verðbréfaviðskiptum en á öðrum sviðum, enda geti hver dagur skipt máli fyrir verðmæti verðbréfa og gætu rúmir frestir til athugasemda leitt til pess að samningsaðili tæki ekki aðeins mið af upplýsingum, sem lágu fyrir pegar viðskipti voru gerð, heldur einnig síðari upplýsingum.

Porsteinn hafði tapað rúmum 23,5 milljónum kr. á afleiðutengdu skuldabréfi sem eignastýringin hafði keypt fyrir hans hönd. Vegna pessa vildi eignastýringin vinna upp tapið með gjaldeyrisstýringu. Porsteinn skrifaði í kjölfarið undir samning um gjaldeyrisstýringu. Framlag Porsteins var metið 22 milljónir króna. Hann greiddi pó ekkert vegna stýringarinnar en tapið af skuldabréfinu var flutt inn í gjaldeyrisstýringuna pannig að upphafsstaðan í henni var neikvæð sem nam tapinu af skuldabréfinu. Pegar bankinn var tekinn yfir af Fjármálaeftirlitinu nam tap gjaldeyrisstýringarinnar að meðtöldu tapi vegna skuldabréfsins um 103,6 milljónum króna. Pví var mótmælt af hálfu Porsteins par sem viðskipti með gjaldeyri hefðu farið fram á óeðlilegu gengi. Byggt var á pví að í fjögur skipti hefði verið seldur gjaldeyrir fyrir hönd Porsteins á gengi sem engin stoð hefði verið fyrir.

Fengnir voru dómkvaddir matsmenn til að leggja mat á viðskiptin. Í matsgerð peirra kom fram að pað væri markaðsvenja að miðlun legði á álag á stundargengi og vaxtamun framvirkra samninga sem póknun fyrir viðskiptin. Venjan í stórum viðskiptum væri að álagið væri ekki meira en 2-5 aurar en frávik upp á tugi aura eða 27,87 kr. eins og í málinu gætu ekki talist innan eðlilegra marka. Рað var pví mat matsmanna að í stað taps upp á rúmar 80 milljónir af gjaldeyrisstýringunni hefði átt að vera hagnaður sem næmi rúmum 72 milljónum að teknu tilliti til pess taps sem var fært yfir vegna skuldabréfsins.

Hæstiréttur staðfesti dóm héraðsdóms um að Glitnir hefði brotið gegn ákvæðum um góða viðskiptahætti og skyldu um að hafa hagsmuni viðskiptavinar að leiðarljósi. Vegna pessa hefði bankinn bakað sér skaðabótaskyldu. Ekki var fallist á kröfu Glitnis um að pessi krafa væri niðurfallin vegna tómlætis vegna pess að Porsteinn var aldrei upplýstur um pennan mikla gengismun. Pví var 72 milljóna króna krafa Porsteins vegna gjaldeyrisstýringarinnar viðurkennd pó að hann hafi aldrei lagt fram neina fjármuni til hennar. 


\subsubsection{Mál nr. 222/2013, Glitnir gegn Ottó Birni Ólafssyni}

Ottó Björn Ólafsson lýsti skaðabótakröfum við slitameðferð Glitnis vegna framvirks samnings um skuldabréfakaup sem starfsmenn Glitnis höfðu gert fyrir hönd Ottós. Ottó hafði gert samning við Glitni um einkabankapjónustu sem stýrði fjárfestingum fyrir hann samkvæmt fyrir fram ákveðinni fjárfestingastefnu. Ottó hafði skrifað undir almenna skilmála um einkabankapjónustu. Í skilmálunum kemur m.a. fram að viðskiptavinir, sem eru flokkaðir sem fagfjárfestar, geti óskað eftir pví að fjárfestingar í einkabankapjónustu nái til óskráðra verðbréfa. Ottó var flokkaður sem almennur fjárfestir.

Ottó krafðist skaðabóta vegna taps af gjaldeyrisstýringu. Málsaðstæður voru pær að eignastýringin hafði gert framvirkan samning um kaup á afleiðutengdu skuldabréfi útgefnu af Spron par sem vextir af bréfinu réðust af hlutabréfaverði í Straumi banka. Rúmlega 46 milljóna króna tap varð á peim viðskiptum. Eignastýringin bauð Ottó í kjölfarið að færa tapið inn í gjaldeyrisstýringu með pað аð markmiði að vinna upp tapið - sem hann páði. Vegna viðskiptanna purfti Ottó að leggja fram 41 milljón króna í tryggingu en ekki pótti sýnt fram á að hann hefði greitt fjárhæðina og pví var skaðabótakröfu vegna hennar hafnað. Glitnir fór fram á að hann myndi greiða fjárhæð sem nam tapinu af framvirka samningnum.

Hæstiréttur hafnaði pví á grundvelli peirra skilmála sem viðskiptavinurinn hafði undirritað og heimiluðu aðeins fagfjárfestum að eiga viðskipti með óskráð verðbréf. Par sem Ottó var almennur fjárfestir og umræddar afleiður voru ekki skráðar á verðbréfamarkað pá var ekki talið að einkabankapjónustunni hefði verið heimilt að fjárfesta í peim fyrir hans hönd. Vegna pessa var kröfu Glitnis um uppgjör á tapi vegna samninganna hafnað.

\subsubsection{Mál nr. 158/2015, Eignarhaldsfélag RS hf. gegn SPB hf.}

Deilt var um skiptasamning sem hafði verið gerður á milli RS og SPB hinn 5. október 2007. Skiptasamningurinn fól pað í sér að viðskiptavinurinn tók á sig áhættu af verðlækkun tiltekinna skuldabréfa útgefnum af Exista hf. og skyldi greiða bankanum ef bréfin lækkuðu í virði á samningstímanum. Bankinn tók áhættu af hugsanlegri verðhækkun bréfanna og bar að greiða RS pá hækkun sem yrði á virði bréfanna á samningstímanum. Við bankahrunið urðu skuldabréf Exista nánast verðlaus.

RS krafðist pess að samningurinn yrði dæmdur ógildur par sem félagið hefði ekki mátt stunda slík afleiðuviðskipti vegna pess að pað hefði ekki uppfyllt kröfur sem eru gerðar í lögum um slík viðskipti. Vísaði RS til skyldu fjármálafyrirtækja um upplýsingaöflun og flokkun fjárfesta. Pað lá fyrir í málinu að SPB hafði ekki aflað sér upplýsinga um eða flokkað RS og pví naut félagið stöðu almenns fjárfestis. Pví var haldið fram af RS að „samkvæmt íslenskum samningarétti sé samningur við aðila, sem að lögum sé ekki hæfur til að standa að slíkum löggerningi, ógildur frá upphafi“. Einnig kom fram í máli RS að „,[m] eginregla laga um verðbréfaviðskipti sé sú að fjármálafyrirtæki megi ekki veita fjárfestum ráðgjöf eða eiga við pá afleiðuviðskipti af peim toga sem skiptasamningarnir séu, nema peim sem pau hafi metið með lögmæltum hætti“. Pá kom fram í máli RS að pað skipti engu að engin ógildingarákvæði væri að finna í lögum um verðbréfaviðskipti par sem „,[s] lík skýring á verðbréfaviðskiptalögunum samræmist peirri meginreglu Evrópuréttar og EES réttar að einstaklingur eða lögaðili sem njóta eigi verndar ESB/EES reglna, skuli eiga áhrifarík réttarúrræði til að ná rétti sínum ef brotið er gegn peim reglum“.

Hæstiréttur staðfesti dóm héraðsdóms, par sem kom fram að par sem samningurinn var gerður áður en ný lög um verðbréfaviðskipti tóku gildi pá giltu pau ekki um pennan samning. Pá sagði einnig að fyrir lægi að RS væri umsvifamikill fjárfestir bæði á Íslandi og erlendis og ótvírætt að hann gerði sér grein fyrir peirri áhættu sem fælist í samningunum. Hann hafði einnig undirritað almenna skilmála SPB um markaðsviðskipti par sem kemur fram að viðskiptavinurinn geri sér grein fyrir peirri áhættu sem felist í samningunum og muni hann leita sér utanaðkomandi ráðgjafar telji hann pörf á pví. Vegna alls pessa var ekki talið að RS hefði verið óhæft til að standa að afleiðusamningum og pví sampykkti héraðsdómur kröfu SPB um að RS yrði gert að standa við samninginn. 


\subsection{Samantekt}

Megintilgangur MiFID-tilskipunarinnar var að auka neytendavernd fjárfesta. Рað var gert með pví að leggja auknar kvaðir á fjármálafyrirtæki um upplýsingagjöf til viðskiptavina og að pau skuli tryggja að viðskiptavinurinn hafi pekkingu og reynslu til að eiga viðskipti með pær fjármálaafurðir sem hann óskar eftir að eiga viðskipti með. Prátt fyrir petta er pað niðurstaða Hæstaréttar að í lögunum séu engar heimildir til ógildingar á samningum pótt fjármálafyrirtæki sinni ekki pessum skyldum sínum.

Viðskiptavinir geta pó höfðað skaðabótamál og krafist skaðabóta telji peir fjármálafyrirtæki ekki hafa farið að lögum og með pví valdið sér skaða. Hér hafa verið reifuð mál par sem viðskiptavinum einkabankapjónustu hafa verið dæmdar skaðabætur í slíkum tilvikum. Pó ber að hafa í huga að Hæstiréttur vísaði í peim málum einnig til skilmála sem viðskiptavinirnir undirrituðu um pjónustuna. Í peim kemur fram að aðeins fagfjárfestum sé heimilt að óska eftir pví að eiga viðskipti með óskráð bréf.

Hæstiréttur hefur einnig komist að peirri niðurstöðu að pað sé ekkert í lögum sem banni almennum fjárfestum að stunda afleiðuviðskipti. Að pví marki sem afleiðurnar eru skilgreindar sem einfaldir fjármálagerningar er krafa um upplýsingagjöf minni. Niðurstaða Hæstaréttar hefur verið sú að framvirkir samningar með hlutabréf séu ekki flóknir fjármálagerningar og rökstuddi Hæstiréttur pá niðurstöðu sína m.a. með pví að áhættan af framvirkum samningi sé sú sama fyrir viðskiptavininn og ef um væri að ræða lántöku fyrir kaupum á hlutabréfum. Pessi skilgreining er ekki í samræmi við skilgreiningu Evrópusambandsins sem skilgreinir alla afleiðusamninga sem flókna fjármálagerninga (Committee of European Securities Regulators, 2009, bls. 4).

\section{Gengisviðmiðun gjaldmiðlasamninga}

Við uppgjör gjaldmiðlasamninga, hvort sem um er að ræða skiptasamninga, framvirka samninga, valrétti eða aðrar gjaldmiðlaafleiður, pá skiptir pað gengi, sem er til viðmiðunar í uppgjörinu, miklu máli. Viðskipti með íslensku krónuna fara fram á nokkrum mismunandi mörkuðum og nokkrir aðilar skrá og birta gengi hennar opinberlega, t.d. Seðlabanki Íslands, Seðlabanki Evrópu og fleiri seðlabankar, og einnig skrá viðskiptabankar kaup- og sölutilboð sín sem og miðgengi. Yfirleitt er ekki mikill munur á gengisskráningu milli aðila eða á gengi milli markaða enda myndu pá verða til högnunartækifæri. Pó geta pær aðstæður komið upp, pegar markaðir eru ekki fyllilega frjálsir, eins og gerðist hér á landi í kjölfar bankahrunsins. Ekki er alltaf kveðið á um við hvaða gengisskráningu skuli miða í samningum eða pað er á einhvern hátt óskýrt.

\subsection{Helstu lagaákvæði og aðstæður á markaði}

Í 19. gr. laga nr. 36/2001 um Seðlabanka Íslands segir að Seðlabankinn skuli skrá gengi íslensku krónunnar gagnvart helstu gjaldmiðlum og að miða skuli við pá gengisskráningu í „dómsmálum, opinberum samningum og öðrum samningum“ par sem ekki er kveðið sérstaklega á um við hvaða gengisskráningu skuli miða. Fram kemur í lögunum að Seðlabankinn hafi heimild til að skrá gengi pegar skipulegir gjaldeyrismarkaðir eru ekki starfandi. Pá segir í lögunum að Seðlabankinn skuli setja reglur um skipulega gjaldeyrismarkaði sem hann hefur gert með reglum nr. 1098/2008 um gjaldeyrismarkað sem komu í stað eldri reglna nr. 912/2002 um sama efni.

Samkvæmt reglunum skal Seðlabankinn skrá opinbert viðmiðunargengi evru gagnvart krónu ${ }^{4}$ á grundvelli tilboða allra viðskiptavaka. Gengi annarra gjaldmiðla reiknar Seðlabankinn út frá gengi evru. Peir sem óska eftir að verða viðskiptavakar á gjaldeyrismarkaði purfa að hafa „ótakmarkað starfsleyfi til gjaldeyrisviðskipta“. Pær skyldur, sem viðskiptavakar gangast undir, eru að peir skuldbinda sig til að leggja reglulega fram bindandi kaup- og sölutilboð í upplýsingakerfi Reuters. Tilboðin skulu uppfærð á a.m.k. 30

4 Í eldri reglum var miðað við Bandaríkjadal í stað evru. 
sekúndna fresti. Miða skal við að tilboðin, sem viðskiptavakinn leggur fram, séu fyrir 100.000 evrur nema annað sé tekið fram. Markaðsaðilum er skylt að eiga viðskipti við Seðlabanka Íslands í samræmi við reglurnar en Seðlabankanum er ekki skylt að eiga viðskipti við aðra markaðsaðila. Markaðsaðilar eru viðskiptavakar auk Seðlabanka Íslands. Seðlabankinn ákveður fyrir hvaða gjaldmiðla gengi er skráð (Reglur um gjaldeyrismarkað nr. 1098/2008).

Viðskiptabankarnir prír, Glitnir hf., Landsbanki Íslands hf. og Kaupping hf., gegndu hlutverki viðskipavaka á gjaldeyrismarkaði við hrun fjármálakerfisins. A tímabilinu 7.-9. október árið 2008 voru peir allir teknir yfir af Fjármálaeftirlitinu og hættu að sinna pví hlutverki sínu. Vegna pessa og peirrar óvissu, sem ríkti, féll gengi íslensku krónunnar gagnvart öðrum gjaldmiðlum. Seðlabankinn brást við pessari próun með aðgerðum til að hafa áhrif á gengi krónunnar. Pví var ljóst að opinber gengisskráning bankans endurspeglaði ekki markaðsvirði íslensku krónunnar gagnvart öðrum gjaldmiðlum á pessum tíma.

Hinn 7. október 2008 sendi Seðlabankinn frá sér tilkynningu par sem kom fram að hann ætlaði að grípa til aðgerða til að styðja við gengi krónunnar. Gengið hafði pá lækkað hratt. Einnig kom fram að Seðlabankinn ætlaði að eiga í viðskiptum sem tækju mið af pví að gengisvísitalan væri 175 stig sem samsvaraði pví að gengi krónu gagnvart evru næmi 131 kr. (Seðlabanki Íslands, 2008a). Daginn eftir sendi Seðlabankinn frá sér aðra tilkynningu par sem kom fram að bankinn hefði „í tvo daga átt viðskipti með erlendan gjaldeyri á öðru gengi en myndast hefur á markaði“ en hann ætlaði ekki að halda pví áfram (Seðlabanki Islands, 2008b). Í framhaldi af pessu sendi bankinn innlánsstofnunum tilmæli um tímabundna temprun á útflæði gjaldeyris par sem kom m.a. fram að „[f]orðast ætti að nýta gjaldeyri, sem kemur inn í bankana, til fjármálatengdra gjaldeyrisviðskipta af neinu tagi“. Var petta gert vegna mikillar markaðsröskunar vegna pess sem áður hafði gerst (Seðlabanki Íslands, 2008c). Seðlabankinn hóf í kjölfarið dagleg uppboð á gjaldeyri.

Mynd 1 sýnir veltu á millibankamarkaði með gjaldeyri og gengisvísitöluna. Á myndinni sést að velta á innlendum gjaldeyrismarkaði minnkaði verulega eftir setningu neyðarlaganna í byrjun október 2008 sem hömluðu frjálsum viðskiptum á markaði. Veltan, sem pó var, kom til vegna daglegra gjaldeyrisútboða Seðlabankans.

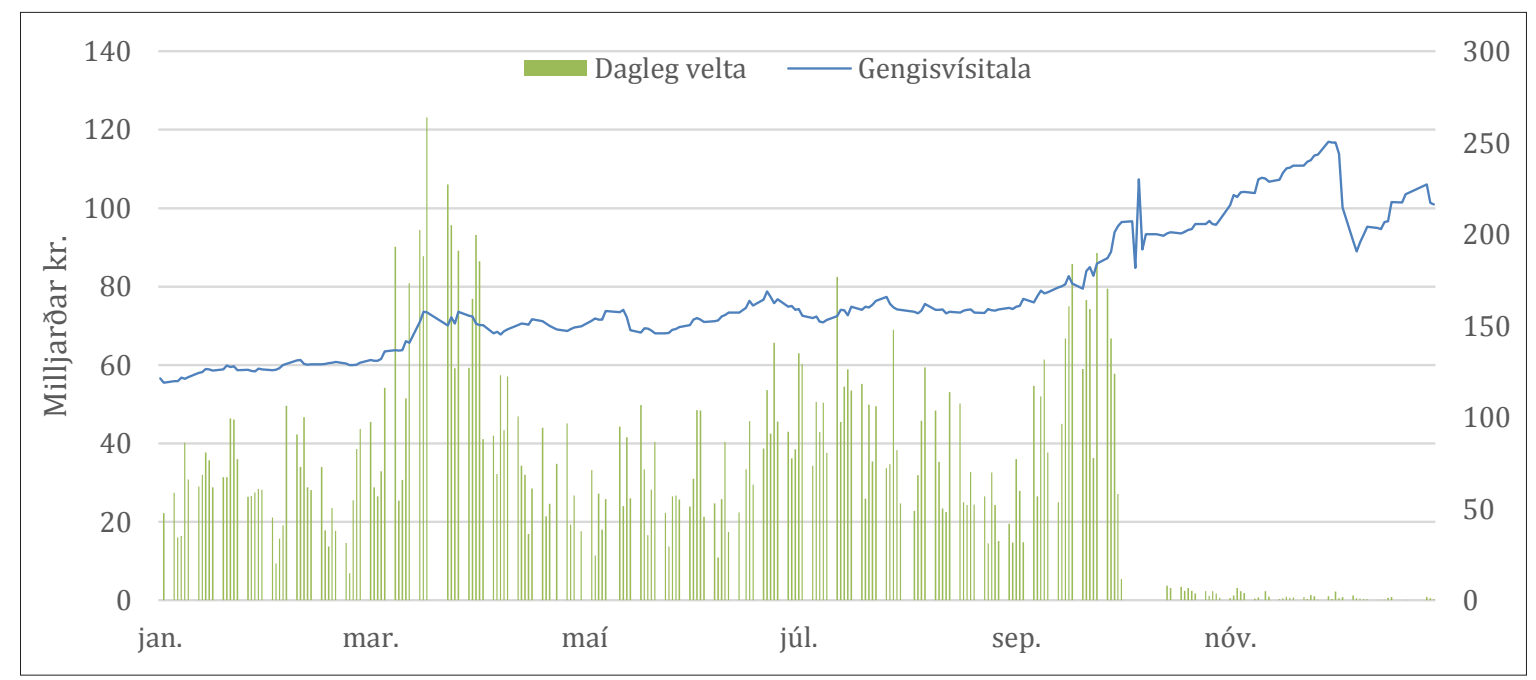

Mynd 1. Velta á gjaldeyrismarkaði (vinstri ás) og gengisvísitala (hægri ás) árið 2008 Heimild: Seðlabanki Íslands.

Hinn 28. nóvember 2008 voru tilmælin um temprun útflæðis felld úr gildi pegar breytingar höfðu verið gerðar á lögum um gjaldeyrismál sem heimiluðu Seðlabankanum að setja á reglur sem takmörkuðu fjármagnsflutning milli landa. Seðlabankinn nýtti sér pá heimild og setti reglur nr. 1082/2008 um gjaldeyrismál sem í daglegu tali eru nefnd fjármagnshöftin (Seðlabanki Íslands, 2008d). Höftin bönnuðu allan flutning á fjármagni til og frá landinu 
nema til að greiða fyrir vöru og pjónustu auk pess sem heimilt var að greiða vexti og afborganir af erlendum lánum sem höfðu verið tekin fyrir gildistöku reglnanna. Reglurnar bönnuðu kaup erlendra aðila á verðbréfum í krónum, nema að peir ættu krónur fyrir gildistökuna, sem og kaup innlendra aðila á verðbréfum í erlendri mynt. Pó var heimilt að endurfjárfesta arð- og vaxtagreiðslum í erlendri mynt sem og söluandvirði erlendra eigna. Í 5. gr. reglnanna er fjallað um afleiðusamninga og par er lagt bann við afleiðusamningum sem fela í sér viðskipti með íslenska krónu gegn erlendum gjaldeyri að undanskildum samningum um vöru- og pjónustuviðskipti (Reglur um gjaldeyrissmál nr. 1082/2008).

Seðlabanki Evrópu heldur utan um gengisskráningu fjölmargra gjaldmiðla gagnvart evru og birti bankinn gengi evrunnar gagnvart íslensku krónunni fram til 3. desember 2008. Bankinn hóf að nýju að birta gengi evru gagnvart íslensku krónunni pann 1. febrúar 2018 eftir rúmlega 9 ára hlé. Gengisskráningin byggir á samráði bankans við aðra seðlabanka og á hún að endurspegla markaðsaðstæður hverju sinni. Pó er einnig tekið fram að gengisskráning bankans sé einungis til upplýsingar: „The rates are intended for information purposes only" (European Central Bank, e.d).

\subsection{Dómar Hæstaréttar}

\subsubsection{Mál nr. 773/2013, Síminn hf. gegn Glitni hf.}

Síminn hafði gert gjaldmiðlaskiptasamninga við Glitni og sex peirra voru á lokagjalddaga á árinu 2008 eftir að Glitnir hafði verið tekinn yfir af Fjármálaeftirlitinu. Aðilar voru sammála um að samningarnir skyldu gerðir upp á lokagjalddaga peirra en ósammála um við hvaða gengi skyldi miða. Síminn fór fram á að miðað yrði við skráð gengi Seðlabanka Evrópu frekar en gengi Seðlabanka Íslands. Vísaði Síminn til reglna, sem hann hafði undirritað, sem og SFF-skilmálanna par sem kemur fram að útreikningur, sem fer fram við uppgjör, skuli vera byggður á markaðsskilyrðum.

Héraðsdómur Reykjavíkur komst að peirri niðurstöðu að ekki væri að finna nein ákvæði í samningum milli aðilanna eða peim skilmálum, sem giltu um viðskiptin, um við hvaða gengisskráningu skyldi miða. Pví skyldi miða við gengisskráningu Seðlabanka Íslands samkvæmt lögum um bankann. Dómurinn vísaði til pess að starfandi hefði verið uppboðsmarkaður á vegum Seðlabanka Íslands á öllum lokagjalddögum samninganna og viðskipti hefðu farið fram á skráðu gengi bankans. Pá breytti pað engu að mati dómsins pó að gengið réðist ekki af frjálsum viðskiptum í hvívetna.

Hæstiréttur staðfesti dóm héraðsdóms og lagði jafnframt áherslu á að samkvæmt lögum er Seðlabankanum skylt að skrá gengi krónunnar á hverjum peim degi sem skipulegir gjaldeyrismarkaðir eru almennt starfandi. Pá hafi hann einnig heimild samkvæmt lögum til að ákvarða gengið pegar skipulegir gjaldeyrismarkaðir eru ekki starfandi.

\subsubsection{Mál nr. 39/2016, Brim hf. gegn LBI ehf.}

Í málinu var deilt um viðmiðunargengi í gjaldmiðlasamningum. Meðal pess sem Brim hélt fram var að samningarnir skyldu falla niður á grundvelli pess að alvarlegir hagsmunaárekstrar hefðu verið á milli bankans og Brims sem hefðu varðað við 8. gr. laga nr. 108/2007. Greinin leggur skyldu á fjármálafyrirtæki að gera allar tiltækar ráðstafanir til koma í veg fyrir hagsmunaárekstra við viðskiptavini sína.

раð var mat Brims að Landsbankinn hefði hvatt félagið og fleiri viðskiptavini til að taka stöðu með íslensku krónunni ${ }^{5}$ prátt fyrir að bankanum hefði verið ljóst að margar vísbendingar væru um yfirvofandi gengislækkun krónunnar. Einnig hélt Brim pví fram að Landsbankinn hefði haft ríka hagsmuni af falli krónunnar. Pví til stuðnings hélt Brim pví fram að afkoma bankans á síðustu 20 mánuðunum fyrir hrun hefði verið borin uppi af gengishagnaði vegna lækkunar á gengi íslensku krónunnar.

5 Gera framvirka samninga um sölu á erlendum gjaldeyri fyrir krónur pannig að viðkomandi hagnast ef gengi krónunnar styrkist gagnvart erlendum gjaldmiðlum en tapar ef pað veikist. 
Matsmenn voru dómkvaddir til að meta gengisáhrif á efnahags- og rekstrarreikninga bankans. Niðurstaða matsins var sú að áhrif gengisbreytinga á efnahags- og rekstrarreikning bankans á fyrri helmingi ársins 2008 hefðu numið tæpum 64 milljörðum króna. Bókfært eigið fé bankans nam á pessum tíma tæpum 202 milljörðum króna og heildarhagnaður tímabilsins nam rúmum 29 milljörðum króna (Landsbanki, 2008b). Pví hefði verið tap á tímabilinu ef ekki hefði komið til gengishagnaðar. Pví var haldið fram í málinu að Landsbankinn hefði haft beina hagsmuni af pví að gengi krónunnar myndi lækka og að bankinn hefði ekki leyft viðskiptavinum sínum að taka stöðu gegn krónunni.

Hæstiréttur komst að peirri niðurstöðu að málið væri ekki vanreifað af hálfu Landsbankans varðandi gengisviðmiðun. Hann féllst á pau rök Landsbankans að honum hefði verið heimilt samkvæmt almennum skilmálum bankans að umreikna pær erlendu myntir, sem Brim átti að greiða, í íslenskar krónur m.v. gengisskráningu Seðlabanka Íslands par sem Brim stóð ekki skil á peim í samræmi við samninginn.

Í dómi Hæstaréttar sagði að pekkt væri að bankar leituðust við að gera samninga sem vega hver upp á móti öðrum til að draga úr áhættu en einnig að bankar gætu haft sjálfstæða hagsmuni af próun undirliggjandi eignar par á meðal gengi gjaldmiðla. Dómurinn tók undir pað að gögn bentu til pess að bankinn hefði hagnast a.m.k. til skamms tíma á lækkun gengis íslensku krónunnar. Að mati dómsins voru pó ekki lögð fram fullnægjandi gögn sem sýndu að bankinn hefði markvisst stuðlað að gengislækkun eða búið yfir sértækum upplýsingum sem honum væri skylt að upplýsa viðskiptavini sína um. Kröfu Brims var pví hafnað.

\subsection{Samantekt}

Í peim tveimur málum, sem voru reifuð hér að framan, giltu SFF-skilmálarnir sem og skilmálar bankanna. Í samningunum var ekki sérstaklega tekið fram við hvaða gengisskráningu skyldi miða og vegna pess komst Hæstiréttur að peirri niðurstöðu í báðum málum að miða skyldi við gengi Seðlabanka Íslands. Рað breytti engu pó að gengisskráningin hefði ekki byggt á markaðsaðstæðum enda hefði bankinn haft heimild í lögum til að skrá gengi pegar gjaldeyrismarkaðir voru ekki starfandi. Рað skipti engu máli - að mati dómstóla - pótt fram hefði komið í SFF-skilmálunum að útreikningar skyldu byggðir á markaðsaðstæðum.

Í máli Símans gegn Glitni nr. 773/2013 (sjá 3.2.1) mátu dómkvaddir matsmenn markaðsgengi krónunnar gagnvart nokkrum gjaldmiðlum, par á meðal evru. Aðferðafræði matsmanna byggðist á pví að finna vegið meðalgengi í viðskiptum yfir pann tíma sem hefði tekið að loka viðkomandi samningum. Byggt var á gengisskráningu frá upplýsingaveitunni Reuters Dealing. Pau gögn endurspegluðu best gjaldeyrisviðskipti í frjálsum viðskiptum að mati matsmanna.

Mynd 2 sýnir gengi evru gagnvart íslensku krónunni samkvæmt skráningu Evrópska seðlabankans (blá lína), Seðlabanka Íslands (græn lína) og gengismati matsmanna samkvæmt Reuters Dealing á premur dögum (gráir punktar). Eins og sést á myndinni var mikill samhljómur milli gengisskráningar seðlabankanna tveggja fram í október 2008 en punktalínan sýnir dagslokagengi pann 3. október eða síðasta viðskiptadag áður en neyðarlögin voru sett og tveimur viðskiptadögum áður en Seðlabankinn tilkynnti um að hann ætlaði að festa gengisvísitöluna í 175 stigum.

Eins sjá má af myndinni pá getur munað umtalsverðum fjárhæðum eftir pví við hvaða gengi er miðað við uppgjör á samningum. Hæstiréttur hefur verið afdráttarlaus með að miða skuli við skráð gengi Seðlabanka Íslands sé ekki önnur gengisskráning tiltekin og breytir pá engu hvort gengið hafi myndast á markaði eða ekki. Pá hefur Hæstiréttur staðfest niðurstöðu héraðsdóms varðandi pað að ekki hafi verið sýnt fram á að bankarnir ${ }^{6}$ „hafi

6 Málið fjallaði um viðskipti Landsbanka Íslands en samkvæmt skýrslu Rannsóknarnefndar Alpingis (2010) tók bankinn svipaða stöðu á gjaldeyrismarkaði og hinir viðskiptabankarnir tveir og pví var líklegt að Hæstiréttur kæmist að sömu niðurstöðu varðandi hina tvo. 
markvisst stuðlað að lækkun íslensku krónunnar eða búið yfir sértækum upplýsingum um próun gengis hennar sem honum var skylt að upplýsa viðskiptavini sína um" (Brim hf. gegn LBI ehf., 2016).

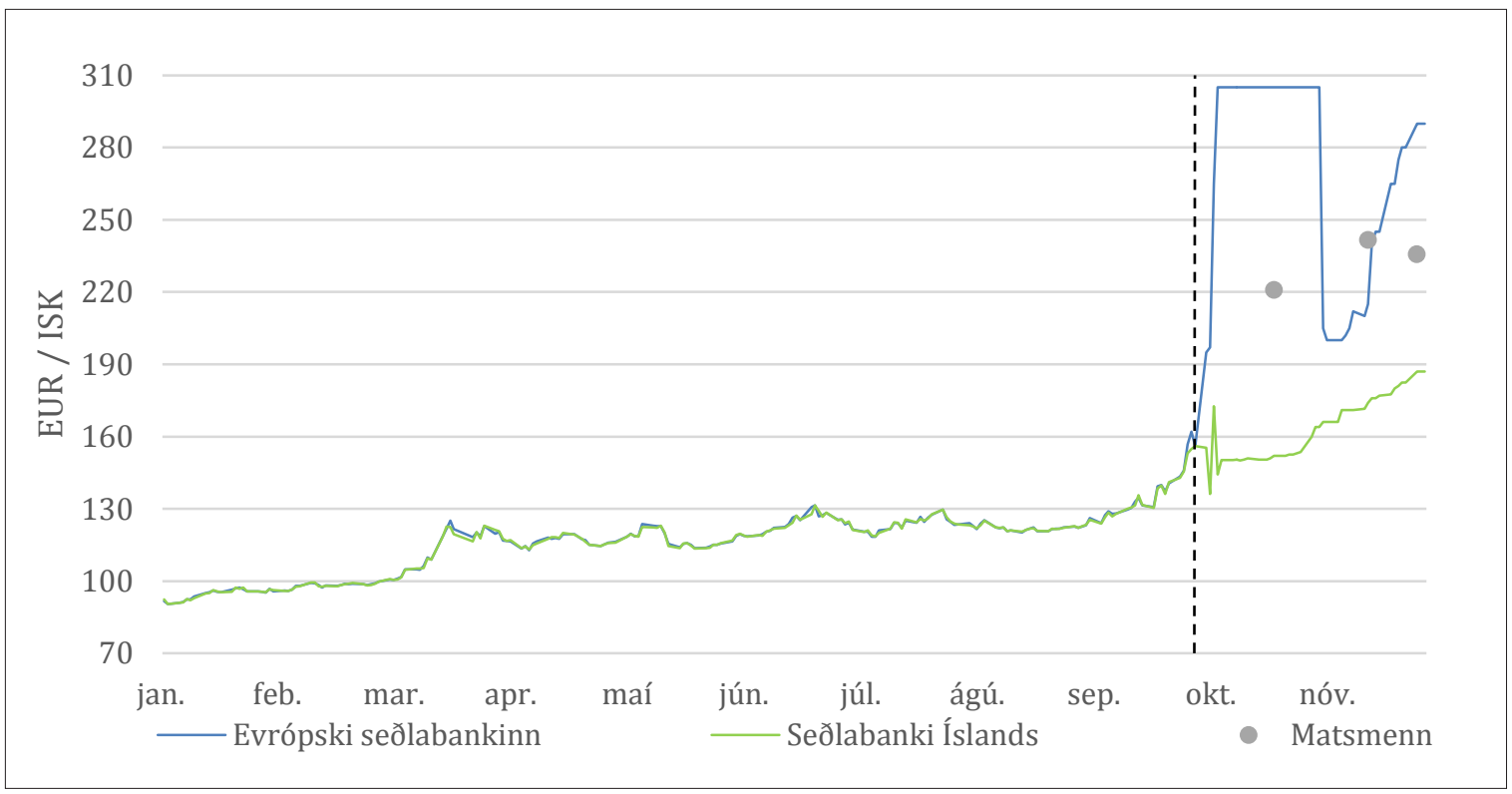

Mynd 2. Gengi krónu gagnvart evru árið 2008.

Heimildir: Seðlabanki Íslands, Evrópski seðlabankinn og dómur Hæstaréttar í máli nr. 773/2013.

\section{Reiknireglur við uppgjör}

Í SFF-skilmálunum kemur fram að falli samningur úr gildi vegna vanefndar skuli sá sem olli vanefndinni bæta mótaðilanum pað tjón sem hann kann að hafa orðið fyrir. Par segir einnig að við útreikning á virði samnings skuli beita núvirðingaraðferð sem byggir á markaðsaðstæðum. Hér verða reifuð tvö mál par sem var deilt um uppgjörsaðferð fyrir dómstólum.

\subsection{Dómar Hæstaréttar}

\subsubsection{Mál nr. 421/2011, Glitnir banki hf. gegn Marel hf.}

Glitnir og Marel höfðu gert með sér nokkra gjaldmiðlaskiptasamninga. Málsaðilar höfðu samið sín á milli um öll deilumál varðandi samningana nema hvaða uppgjörsaðferð skyldi beitt. Glitnir vildi beita núvirðingaraðferð en Marel svokallaðri uppsöfnunaraðferð.

Í dómi Hæstaréttar kom fram að núvirðingaraðferð felur pað í sér að gera aðilana eins setta og ef samningurinn hefði verið efndur á gjalddögum. Pannig er stuðst við pær forsendur að allar vaxtagreiðslur og höfuðstólsgreiðslur hafi farið fram í samræmi við samninginn og pær greiðslur eru núvirtar m.v. pann dag sem samningunum var lokað. Uppsöfnunaraðferðin byggir á pví að samningurinn hafi verið gerður upp pegar honum var lokað, p.e. ekki er gert ráð fyrir frekari greiðslum samkvæmt samningnum heldur er staða hans reiknuð m.v. pann dag sem samningnum var lokað. Höfuðstólsgreiðslur og áfallnar vaxtagreiðslur eru pannig skuldajafnaðar hvorar á móti öðrum.

Í pessu máli hafnaði bankinn pví að efna samningana eins og Marel hafði óskað eftir. Pað var pví bankinn sem vanefndi samningana með pví að greiða ekki vaxtagreiðslu á gjalddaga hennar. Við vanefnd hans á samningunum virkjaðist heimild Marel til að rifta peim samkvæmt skilmálum. Samkvæmt SFF-skilmálunum, sem giltu um viðskiptin, varð að tilkynna riftunina skriflega sem Marel gerði pó ekki. Bankinn hélt pví m.a. fram að skapast hefði sú markaðsvenja að gera samninga sem pessa upp með núvirðingaraðferð. Undir pað sjónarmið tók dómurinn ekki. 
Hæstiréttur taldi að par sem bankinn hefði vanefnt samninginn yrði ákvæði í skilmálunum ekki notað honum til hagsbóta par sem pau ákvæði miða að pví að bæta peim sem verður fyrir vanefnd pað tjón sem hann verður fyrir. Bankinn hélt pví einnig fram að par sem Marel rifti samningnum ekki skriflega, eins og kveðið er á um í SFF-skilmálunum, pá hefði Marel í reynd ekki rift samningnum. Héraðsdómur komst að peirri niðurstöðu að fyrirsjáanleg vanefnd hefði orðið við fall bankans og hún orðið raunveruleg nokkrum dögum síðar pegar bankinn átti að greiða vaxtagreiðslu sem hann greiddi ekki. Marel hafði einnig í tvígang lýst pví yfir að félagið vildi efna samningana til lokagjalddaga og féllst dómurinn á að Marel skyldi ekki gjalda fyrir pað að hafa ekki rift samningnum skriflega. Pví skyldi niðurstaðan vera að gera Marel eins sett og að félagið hefði rift samningnum. Var talið að uppsöfnunaraðferðin væri best til pess fallin að gera Marel eins sett og að samningunum hefði verið rift. Hæstiréttur staðfesti dóm héraðsdóms.

\subsubsection{Mál nr. 127/2014, Kaupping hf. gegn Reykjavíkurborg}

Kaupping og Reykjavíkurborg höfðu gert með sér gjaldmiðla- og vaxtaskiptasamninga sem Reykjavíkurborg rifti í kjölfar hrunsins. Að mati Kauppings var riftunin óheimil. Borgin hafði gert samningana til að verja sig gegn gengisáhættu af erlendum lánum sem hún hafði tekið. Samningarnir voru til nokkuð langs tíma eða fimm ára. Að mati Kauppings hafði komið til vanefndar af hálfu borgarinnar pegar hún rifti samningunum og pví gjaldfelldi Kaupping pá og vildi uppgjör í samræmi við núvirðingaraðferðina. Borgin hafði pó aldrei staðfest markaðsskilmála Kauppings sem að hennar mati voru mjög einhliða enda ekkert kveðið á um rétt viðskiptavinarins, ef bankinn stæði ekki í skilum, heldur aðeins um rétt bankans.

Á gjalddögum samninganna hafði skapast sú venja að Kaupping sæi um uppgjör á milli aðila. Uppgjörið var með peim hætti að skuldbindingar hvors aðila fyrir sig voru reiknaðar og sá aðili sem átti að greiða hærri fjárhæð greiddi hinum mismuninn. Í október árið 2008 átti Kaupping að greiða Reykjavíkurborg en gerði pað ekki og í kjölfar pess sendi borgin bankanum bréf par sem hún lýsti yfir riftun á öllum samningunum vegna fyrirsjáanlegrar vanefndar. Hin fyrirsjáanlega vanefnd fólst í pví að Kaupping hafði pegar vanefnt einn samning auk pess sem heimild Fjármálaeftirlitsins til að taka bankann yfir byggðist á pví að hann hefði átt við sérstaka, „fjárhags- og/eða rekstrarerfiðleika“ að stríða, samanber 5. gr. laga nr. 125/2008. Jafnframt byggðist riftunin á peirri staðreynd að afleiðusamningar hefðu ekki verið meðal peirra eigna sem voru færðar yfir í nýja bankann sem ætlað var að taka við hlutverki eldri bankans sem viðskiptabanki.

Bankinn mótmælti riftuninni og sagði að hann liti svo á að samningarnir væru enn opnir og að hann ætti kröfu á borgina ef samningarnir væru neikvæðir fyrir borgina. Ef samningarnir yrðu jákvæðir fyrir borgina ætti hún almenna kröfu á bankann. Bankinn hélt pví fram að ekki hefðu verið færð nægileg rök fyrir pví að fyrirsjáanleg vanefnd hefði verið yfirvofandi á pessum tímapunkti enda hefði síðar komið í ljós að ekki hefðu orðið frekari vanefndir af hálfu bankans. Ástæðan var sú að bankinn var í hagnaði á síðari gjalddögum og purfti ekki að greiða neitt.

Á pessum tíma var fyrirséð að almennar kröfur myndu ekki innheimtast að fullu og pví vísaði borgin til pess að ósanngjarnt væri að hún bæri ein áhættu af próun markaða par sem nokkuð langur tími var eftir af samningunum og alls óljóst hvernig próun á mörkuðum yrði; pað hefði verið allt eins líklegt að próunin yrði borginni hagfelld. Borgin vildi аð farið yrði eftir meginreglum kröfuréttar og aðilar gerðir jafnsettir eins og samningarnir hefðu aldrei verið gerðir.

Héraðsdómur og síðar Hæstiréttur tóku undir pessi rök borgarinnar, bæði varðandi pað að henni hefði verið heimilt að rifta samningunum og að farið skyldi eftir meginreglu kröfuréttar par sem ekki hefði verið tekið fram hvernig samningarnir skyldu gerðir upp við pessar aðstæður og hvorki skilmálar bankans (sem voru ekki undirritaðir af borginni) né SFF-skilmálarnir giltu. Meginreglan er sú að sé samningi rift pá skulu samningsað- 
ilar vera eins settir og samningar hefðu aldrei verið gerðir. Reykjavíkurborg hafði í apríl 2009 sent Kauppingi útreikning á peim greiðslum, sem hún hafði fengið frá bankanum ásamt vöxtum, í kjölfar pess að bankinn hafði ekki svarað óskum borgarinnar um viðræður vegna samninganna. Borgin greiddi pá fjárhæð inn á reikning bankans. Pví féllst Hæstiréttur ekki á að bankinn ætti frekari kröfu á hendur borginni.

\subsection{Samantekt}

Hæstiréttur hefur í báđum peim málum, sem hafa verið rakin hér að framan, vikið frá peirri uppgjörsaðferð sem SFF-skilmálarnir gera ráð fyrir að sé beitt, p.e. núvirðingaraðferð. Annars vegar er pað vegna pess að skilmálarnir verða ekki túlkaðir til hagsbóta fyrir pann sem vanefnir samning. Hins vegar kemst dómurinn að peirri niðurstöðu að par sem sérstakir skilmálar um afleiðuviðskipti hafa ekki verið staðfestir, hvort sem um er að ræða skilmála banka eða SFF-skilmálana, pá gildir hin almenna regla kröfuréttar að við riftun samninga skuli aðilar verða gerðir eins settir og ef samningar hefðu aldrei verið gerðir.

\section{Forsendubrestur}

Fyrrverandi viðskiptavinir hinna föllnu banka hafa gjarnan vísað til brostinna forsenda í sínum málflutningi og pá gjarnan til 33. og 36. gr. laga um samningsgerð, umboð og ógilda löggerninga nr. 7/1936. Í 33. gr. er kveðið á um að ekki megi bera fyrir sig löggerning ef pað er talið óheiðarlegt vegna atvika, sem áttu sér stað áður en hann var gerður, og sá sem ber fyrir sig gerninginn vissi af eða mátti hafa vitað af. Í 36. gr. laganna kemur fram að víkja megi samningi til hliðar ef pað er „,andstætt góðri viðskiptavenju að bera hann fyrir sig“. Meðal mála, sem hafa ratað fyrir dómstóla, eru mál sem varða uppgjör á framvirkum hlutabréfasamningum. Samningarnir eiga pað margir sameiginlegt að undirliggjandi eign voru hlutabréf í bönkunum sjálfum. Bréfin urðu verðlaus í kjölfar bankahrunsins og vildu peir aðilar sem höfðu skuldbundið sig til að kaupa bréfin ekki standa við samningana.

\subsection{Dómar Hæstaréttar}

\subsubsection{Mál nr. 561/2010, Landsbanki Íslands hf. gegn Gift fjárfestingarfélagi ehf.}

Landsbankinn og Gift höfðu gert með sér framvirkan samning um að Gift myndi kaupa hlutabréf í Landsbankanum á lokagjalddaga samningsins. Pegar kom að lokagjalddaga samningsins neitaði Gift að efna samninginn og bar fyrir sig forsendubresti. Í rökstuðningi sínum vísaði félagið m.a. til skýrslu Rannsóknarnefndar Alpingis.

Fram kemur í skýrslunni að pað sé mat rannsóknarnefndarinnar að allir bankarnir hafi reynt að kalla fram óeðlilega eftirspurn eftir hlutabréfum í peim sjálfum. Bent er á að bankarnir hafi mjög sjaldan verið á söluhlið í pöruðum viðskiptum. ${ }^{7}$ Á árinu 2008 voru bankarnir í 44,42\%-46,45\% tilfella á kauphlið í slíkum viðskiptum en aðeins í 0,67\%-1,61\% tilvika á söluhlið. Við petta eignuðust bankarnir mikið magn eigin bréfa sem peir purftu að losa um til að fara ekki upp fyrir lögboðin hámörk um eigin hluti eða purfa að flagga. ${ }^{8}$ Bankarnir losuðu um pessi bréf m.a. með pví að selja pau utan kauphallar og í mörgum tilfellum lánuðu peir fyrir kaupunum með veði í bréfunum sjálfum. Pannig var áhættan af bréfunum áfram hjá bönkunum sjálfum (Rannsóknarnefnd Alpingis, 2010, 4. bindi bls. 62-67). Rannsóknarefnd Alpingis taldi að áhætta af eigin bréfum hafi í mörgum tilfellum verið vanmetin af bönkunum. Við útreikning á lögbundnu eigin fé banka beri að draga frá eigin bréf en í mörgum tilfellum hafi pó áhætta af bréfum, sem bankarnir áttu ekki sjálfir, verið enn hjá bönkunum, t.d. í gegnum lánasamninga par sem bréfin voru að veði. Pví hefðu bankarnir átt að draga frá öll hlutabréf í peim sjálfum sem peir báru áhættuna af. Einnig drógu Landsbankinn og Glitnir ekki frá eigin bréf sem peir höfðu keypt til að verja

7 Viðskipti sem fara fram í kerfi kauphallar par sem kaup- og sölutilboð eru pöruð saman.

8 Senda tilkynningu á markaðinn um að eignarhald félagsins hafi farið yfir ákveðin mörk. 
framvirka hlutabréfasamninga. Af pessum sökum telur nefndin að eigið fé bankanna hafi verið stórlega ofmetið (Rannsóknarnefnd Alpingis, 2010, 3. bindi bls. 17-23).

Í máli Landsbankans gegn Gift vísaði Gift til pess að starfsmenn bankans hefðu mátt vita að verð á hlutabréfum í bankanum endurspeglaði ekki raunverulegt markaðsvirði peirra. Ástæða pess væri óheiðarlegar athafnir starfsmanna bankans og pví væri pað andstætt góðri viðskiptavenju að bankinn bæri samninginn fyrir sig. Hæstiréttur hefur tekið undir að skýrslan gefi vísbendingar um háttsemi bankanna við að halda uppi hlutabréfaverði. Engu að síður telur hann skýrsluna ekki fullnægjandi sönnun fyrir pví að bankarnir hafi beitt blekkingum. Pví hefur dómurinn hafnað pví að víkja samningunum til hliðar á grundvelli 33. eða 36. gr. samningalaga.

Gift hélt pví einnig fram að bankinn gæti ekki efnt skyldur sínar um afhendingu á hlutabréfum sem uppfylltu pau skilyrði sem tiltekin voru í samningnum en par var tekið fram að bréfin væru skráð í kauphöll. Eftir yfirtöku á bankanum voru bréfin afskráð úr kauphöllinni vegna pess að pau voru ekki hæf til skráningar. Jafnframt hélt Gift pví fram að ósanngjarnt væri að fara fram á efndir par sem bréfin væru verðlaus.

Héraðsdómur féllst á pau rök að vegna sérstakra aðstæðna á fjármálamarkaði, sem leiddu til pess að verðbréfin höfðu ekki pá eiginleika sem Gift hafði mátt búast við að bréfin hefðu pegar samningurinn var gerður, pá hefði orðið forsendubrestur. Niðurstaða héraðsdóms var pví að Gift yrði ekki krafið um efndir á samningnum. Hæstiréttur sneri dómnum við og sagði pað eðli framvirkra samninga að veðja á tiltekna verðpróun. Jafnframt vísaði dómurinn til pess að ekkert ójafnræði hefði verið á milli aðilanna. Sú áhætta, sem tekin væri í slíkum viðskiptum, væri ekki takmörkuð við pað að hagnaður eða tap væri innan ákveðinna marka. Varðandi staðhæfingu pess efnis, að hlutabréfin hefðu misst pá eiginleika sem kveðið væri á um í samningnum, sagði Hæstiréttur að sveiflur á virði hlutabréfa gætu verið vegna ýmissa ástæðna og bréf gætu orðið verðlaus óháð skráningu í kauphöll. Vegna eðlis viðskiptanna pá yrði ekki tekið undir pað að víkja bæri samningnum frá.

Í grein Aðalsteins E. Jónssonar (2011) um petta mál segir hann að niðurstaða málsins dragi fram sérkenni framvirkra samninga sem er pað að áhættan af undirliggjandi eign flyst til kaupanda frá seljanda strax við gerð samningsins en ekki á afhendingardegi. Aðalsteinn bendir á að „,[a]ðalskylda afleiðusamninga felst í flutningi áhættu frá einum aðila til annars, en ekki afhendingu tiltekinna verðmæta" og að petta eðli afleiðusamninga skilji pá frá flestum öðrum löggerningum. Að mati Aðalsteins er fordæmisgildi dómsins ekki einskorðað við framvirka samninga með hlutabréf heldur sé hann fordæmisgefandi fyrir allar gerðir afleiðusamninga.

\subsubsection{Mál nr. 509/2013, Einar Pétursson gegn LBI hf.}

Hæstiréttur komst að svipaðri niðurstöðu í máli nr. 509/2013 sem hefur áður verið reifað í kafla 2.2.3. Einar Pétursson, fyrrverandi viðskiptavinur Landsbankans, bar fyrir sig að forsendubrestur hefði orðið. Forsendubresturinn hafi falist í pví að mótaðili hans í samningunum, Landsbankinn, hafi verið viðskiptabanki „sem sé einn helsti orsakavaldur að efnahagskreppu heillar pjóðar". Vísaði Einar m.a. til skýrslu Rannsóknarnefndar Alpingis og umfjöllunar par um bankana. Var pví m.a. haldið fram að ef einhver hafi getað séð að pað stefndi í bankahrun væri pað Landsbankinn.

Hæstiréttur komst að peirri niðurstöðu að framvirkir samningar um hlutabréfaviðskipti væru í eðli sínu áhættusamir og takmarkist ekki við pað að hagnaður eða tap sé innan einhverra marka. Pví sé ekki hægt að halda pví fram að lækkun á hlutabréfaverði sé forsendubrestur. Upplýsingar úr skýrslu Rannsóknarnefndar Alpingis teljast að mati Hæstaréttar ekki fullnægjandi sönnun fyrir peim forsendubresti sem Einar hélt fram að hefði átt sér stað. 


\subsubsection{Mál nr. 93/2011, SPB hf. gegn Porgils Einari Ámundasyni}

SPB hafði gert skiptasamning við Porgils Einar Ámundason um skipti á gjaldmiðlum annars vegar og íbúðabréfi hins vegar. Lokagjalddagi samningsins var í október 2007. Um pað leyti sem kom að lokagjalddaga hafði Porgils samband við bankann og óskaði eftir pví að samningurinn yrði framlengdur um eitt ár sem bankinn féllst á. Bankinn hafði sent Porgils samninginn til undirritunar en hann sinnti pví ekki að undirrita hann og senda til baka. Vegna pessa hélt hann pví fram að samningurinn hefði aldrei komist á. Porgils neitaði að efna samninginn og vísaði hann m.a. til skyldu fjármálafyrirtækja, samkvæmt lögum um verðbréfaviðskipti, til að gera skriflegan samning við viðskiptavini sína sem tiltekur réttindi peirra og skyldur. Einnig kemur fram í markaðsskilmálum bankans, sem viðskiptavinurinn undirritaði, að staðfesta skuli skriflega alla samninga nema stundarsamninga innan tíu daga frá dagsetningu peirra. Að öðrum kosti sé bankanum heimilt að gjaldfella eða loka samningi.

Í dómi Hæstaréttar kom fram að í lögunum sé ekki gerð krafa um að hver samningur skuli staðfestur skriflega heldur sé nóg að pað sé gert í upphafi viðskiptasambands og var sú krafa uppfyllt með staðfestingu á skilmálum bankans. Hæstiréttur benti á að pað sé meginregla fjármunaréttar að gildi samnings sé ekki háð pví í hvaða formi hann sé gerður nema pað leiði beint af lögum. Samkvæmt skilmálum bankans hefur bankinn heimild til að gjaldfella samning berist samningurinn ekki undirritaður af viðskiptavini innan tíu daga en hann er á engan hátt skyldugur til að gera pað. Vegna pessa komst Hæstiréttur að peirri niðurstöðu að samningurinn hefði verið framlengdur pó að viðskiptavinurinn hefði ekki staðfest hann skriflega.

\subsubsection{Mál nr. 184/2012, NVN ehf. og Einar Örn Jónsson gegn Landsbanka Íslands hf.,}

Aðstæður voru með svipuðum hætti og í máli SPB gegn Porgils nr. 93/2011 (sjá 5.1.3). Landsbankinn hafði sent viðskiptavini sínum, Einari Erni Jónssyni, samning í kjölfar fyrirmæla viðskiptavinar en aldrei fengið hann sendan undirritaðan til baka. Í skilmálum, sem viðskiptavinurinn hafði undirritað, kom fram að bankinn skyldi færa efni allra samninga í letur. Með pví að Landsbankinn sendi viðskiptavininum samninginn til undirritunar var talið að bankinn hefði uppfyllt pá skyldu sína. Með vísan til dóms í máli SPB gegn Porgils sló Hæstiréttur pví föstu að gildi einstakra samninga væri ekki háð pví að peir væru undirritaðir af báðum aðilum.

\subsubsection{Mál nr. 112/2015, Eignarhaldsfélag RS ehf. gegn Glitni hf.}

RS hafði gert framvirkan samning við Glitni um kaup á skuldabréfi útgefnu af Kauppingi. Við hrun fjármálakerfisins hafði samningurinn verið framlengdur alls sjö sinnum. Síðasta framlenging samningsins hafði ekki verið undirrituð af viðskiptavininum og hélt hann pví fram að sá samningur hefði aldrei komist á. Hæstiréttur taldi Glitni hafa sýnt fram á að viðskiptavinurinn hafi viljað framlengja samninginn, m.a. með tölvupóstum milli starfsmanna Glitnis og viðskiptavinarins. RS hélt pví einnig fram að par sem Glitnir hefði aldrei afhent skuldabréfið pá hefði bankinn vanefnt samninginn. Í samningi milli aðilanna kom fram að viðskiptavinurinn var beðinn um að hafa samband tveimur virkum bankadögum fyrir lokagjalddaga samningsins til að ljúka honum. Vegna pessa ákvæðis var pað mat dómstóla að viðskiptavininum hefði borið að eiga frumkvæði að efndum samningsins. Pví var pað niðurstaða héraðsdóms, sem Hæstiréttur staðfesti, að viðskiptavininum bæri að greiða kröfu bankans enda var ekki deilt um útreikning hennar.

\subsubsection{Mál nr. 513/2012, Landsbanki Íslands hf. gegn Dynjanda ehf.}

Gamli Landsbankinn höfðaði mál gegn fyrrverandi viðskiptavini sínum, Dynjanda, vegna gjaldmiðlaskiptasamnings sem hafði verið vanefndur af hálfu viðskiptavinarins. Á lokagjalddaga samningsins stóð Landsbankinn við sinn hluta samningsins og greiddi íslenskar krónur inn á reikning viðskiptavinarins sem átti á sama tíma að greiða Landsbankanum 
japönsk jen sem hann gerði ekki. Viðskiptavinurinn hélt pví fram að enginn samningur hefði komist á par sem hann hefði ekki undirritað samninginn. Hæstiréttur komst að peirri niðurstöðu að Landsbankinn hefði sýnt fram á að samningurinn hefði komist á. Pví úrskurðaði Hæstiréttur, með vísan til sömu raka og í öðrum málum sem hér hafa verið reifuð, að ekki sé krafa í lögum um að allir samningar séu gerðir skriflega heldur aðeins að gerður sé skriflegur samningur í upphafi viðskiptasambands. Pá sé pað meginregla fjármunaréttar að samningar skuli standa sama í hvaða formi peir eru.

\subsubsection{Mál nr. 509/2013, Einar Pétursson gegn LBI hf.}

Einar Pétursson hélt pví fram að hlutabréf í íslensku bönkunum hefðu verið gölluð í skilningi lausafjárlaga. Byggt var á pví að opinberar upplýsingar, sem bankarnir og stjórnendur peirra hafi sent frá sér, hafi gefið í skyn að verðmyndun hlutabréfa í bönkunum væri eðlileg og að markaðsverð endurspeglaði raunverulegt verðmæti bréfanna. Bankarnir hafi pó vitað eða mátt vita að verðmyndun á bréfum bankanna á árunum 2007-2008 hefði verið óeðlileg. Pá hafi upplýsingum um innri áhættu og hættu á bankakreppu verið haldið leyndum. Hlutabréf í bönkunum hafi pví ekki samsvarað peim verðmætum sem pau hafi borið með sér og petta hafi Landsbankanum verið ljóst. Auk pess hafi fjárhagsstaða bankans verið pannig að hann hafi ekki verið hæfur til að eiga í slíkum viðskiptum.

Hæstiréttur vísaði til niðurstöðu héraðsdóms sem féllst ekki á petta. Að mati héraðsdóms hafði ekki verið sýnt fram á markaðsmisnotkun, svik eða vanhæfi við gerð samninganna af hálfu Landsbankans. Ásamt pví vísaði dómurinn til pess að hlutabréfaviðskipti væru í eðli sínu áhættusöm og ekki hægt að treysta á verðhækkanir, pað sé ekki forsendubrestur að hlutabréf hækki ekki í verði.

\subsection{Samantekt}

Í peim málum, sem hér hafa verið reifuð, hefur Hæstiréttur komist að peirri niðurstöðu að ekki sé ástæða til að ógilda eða víkja samningi af peirri ástæðu að undirliggjandi eign verði verðlaus. Áhættan af undirliggjandi eign flyst milli aðila við gerð afleiðusamninga en ekki við afhendingu. Pá hefur hann einnig komist að peirri niðurstöðu í fjölmörgum málum að pað sé ekki forsenda samninga að peir séu skriflegir. Lögin kveða aðeins á um að gerður sé skriflegur samningur milli aðila við upphaf viðskiptasambands en engin kvöð er á samningsaðilum um að staðfesta alla samninga sín á milli skriflega. Pví telst pað ekki forsendubrestur ef annar aðili samnings skrifar ekki undir hann enda hafi hann sampykkt samninginn með öðrum hætti. Pá er pað mat dómstóla að hlutabréf bankanna hafi ekki verið gölluð í skilningi lausafjárlaga.

\section{Skuldajöfnun}

Í flestum afleiðusamningum hafa báðir samningsaðilar einhverja skyldu, p.e. peir eiga að afhenda greiðslu eða eign á ákveðnum tíma. Ef samningar eru gerðir upp í reiðufé, p.e. raunveruleg afhending á eign á sér ekki stað eða um er að ræða t.d. vaxtaskiptaviðskipti, pá hvílir skylda á báðum aðilum að afhenda greiðslu. Ef greiðslurnar eru í sömu mynt er yfirleitt óparft að báðir aðilar greiði heldur nægir að sá sem á að greiða hærri greiðslu greiði mismuninn. Petta kallast skuldajöfnun innan samnings. Ef aðilar hafa gert með sér fleiri en einn samning eða viðskiptasamband peirra varðar fleiri skuldbindingar pá getur verið heppilegt að gera pær upp á sama tíma. Pannig getur verið heppilegt að jafna greiðslum milli samninga. Við vanefnd er ekki sjálfgefið að slík skuldajöfnun fari fram og hefur fjöldi slíkra mála ratað fyrir dómstóla.

Pegar íslensku viðskiptabankarnir voru teknir yfir af Fjármálaeftirlitinu pá var hverjum peirra skipt í tvennt, nýja og gamla bankann. Eignum og skuldum viðskiptavina var skipt á milli pessara banka. Í peim tilvikum par sem eignir og skuldir viðskiptavina lentu sínar í hvorum bankanum gat verið uppi óvissa um rétt til skuldajöfnunar. Í tilkynningu, sem Fjármálaeftirlitið sendi frá sér í tilefni af uppskiptingu bankanna, segir: „Framsal kröfurétt- 
inda samkvæmt pessari ákvörðun skal ekki svipta skuldara rétti til skuldajöfnuðar [svo] sem hann átti gagnvart fyrri kröfuhafa eða protabúi hans."

\subsection{Helstu lagaákvæði}

Sextándi kafli laga nr. 21/1991 um gjaldprotaskipti fjallar um kröfur á hendur protabúi. Par kemur fram að allar kröfur gagnvart protabúi falla sjálfkrafa á gjalddaga pegar dómari hefur úrskurðað að búið skuli tekið til gjaldprotaskipta. Kröfur á hendur protabúi sem eru í erlendum gjaldeyri skulu reiknaðar í íslenskar krónur m.v. skráð sölugengi á peim degi sem úrskurður um upphaf gjaldprotaskipta féll. Um skuldajöfnun segir í 100 gr. laganna (Lög um gjaldprotaskipti nr. 21/1991):

Hver sá, sem skuldar protabúinu, getur dregið pað frá sem hann á hjá pví hvernig sem skuld og gagnkröfu er varið ef lánardrottinn hefur eignast kröfuna áđur en prír mánuðir voru til frestdags, hvorki vitað né mátt vita að protamaðurinn átti ekki fyrir skuldum og ekki fengið kröfuna til að skuldajafna, enda hafi krafa protabúsins á hendur honum orðið til fyrir frestdag.

Í 1. mgr. 2. gr. laganna segir um frestdag: „Í lögum pessum telst frestdagur vera sá dagur sem héraðsdómara berst beiðni um heimild til greiðslustöðvunar eða til að leita nauðasamnings eða krafa um gjaldprotaskipti“.

Fimmti kafla laga nr. 108/2007 um verðbréfaviðskipti fjallar um samningsbundið uppgjör afleiðna. ${ }^{9}$ Í 40 . gr. kemur fram að ef aðilar hafa gert með sér samning um skuldajöfnun á afleiðum „við endurnýjun eða við vanefnd, greiðslustöðvun, nauðasamninga eða gjaldprotaskipti“ haldi skuldajöfnunin gildi sínu prátt fyrir ákvæði 100. gr. laga um gjaldprotaskipti. Skuldajöfnunin gengur pannig framar ákvæðum í gjaldprotalögum sem segja að greiðslur úr búinu skuli vera almennar kröfur og að pær hafi purft að verða til að lágmarki premur mánuðum fyrir frestdag. Ekki eru hins vegar sérstök lagaákvæði um skuldajöfnun kröfu eða skuldar vegna afleiðusamninga við skuld eða kröfu vegna annars konar samninga.

Í skilmálum afleiðusamninga er oftast kveðið á um heimildir til skuldajöfnunar. Í ISDAskilmálum (sjá kafla 1.1.1) er fjallað um skuldajöfnun í öðrum kafla rammasamningsins. Ef skuldbinding samkvæmt afleiðusamningi er í sama gjaldmiðli, vegna sömu viðskipta og krafa gagnvart mótaðila pá skal skuldajafna greiðslum hverri á móti annarri. Í pví felst að aðeins sá aðili, sem skuldar hærri fjárhæð, greiðir einungis mismuninn af peim greiðslum sem áttu að fara fram. Einnig er heimilt að jafna greiðslum vegna fleiri samninga sem eru í sama gjaldmiðli og með sama gjalddaga (ISDA, 2002).

Í SFF-skilmálunum (sjá kafla 1.1.2) segir um skuldajöfnun að ef aðilar eru skuldbundnir til að greiða hvor öðrum greiðslu á sama degi í sama gjaldmiðli skuli skuldajafna greiðslunum pannig að einungis komi mismunurinn til greiðslu. Sé vanefnd til staðar á samningi, sem er með erlenda gjaldmiðla undirliggjandi, er mótaðila heimilt að uppreikna pá fjárhæð, sem er í vanskilum, yfir í íslenskar krónur og krefjast greiðslu á peirri fjárhæð. Sama á við um dráttarvexti (Samband íslenskra viðskiptabanka og Samband íslenskra sparisjóða, 1998).

Í skilmálum Arion banka vegna verðbréfaviðskipta segir að bankinn hafi heimild til skuldajöfnunar ef skuldbindingar hafa sama gjalddaga og ef pær falla allar undir skilmálana. Ef skuldbinding er í erlendri mynt hefur bankinn heimild til að umreikna hana í íslenskar krónur og skuldajafna á móti kröfu í íslenskri mynt. Ef skuldbindingar eru gjaldfelldar vegna vanefndar af hálfu viðskiptavinar hefur bankinn heimild til að skuldajafna

9 Bjarki H. Diego (2001a, 2001b) fjallaði í tveimur greinum í Lögmannablaðinu árið 2001 um afleiður og ákvæði laga um samningsbundið uppgjör afleiðna og vísast til peirra greina um nánari umfjöllun um efnið. 
kröfum sínum á móti kröfum viðskiptavinar á hendur bankanum sem falla undir skilmálana. Pessi heimild takmarkar pó ekki rétt bankans til að skuldajafna kröfunum gagnvart öðrum hugsanlegum skuldbindingum bankans við viðskiptavininn (Arion banki, 2012).

\subsection{Dómar Hæstaréttar}

\subsubsection{Mál nr. 15/2012, Porgils Einar Ámundason gegn Landsbanka Íslands hf.}

Porgils Einar Ámundason höfðaði mál gegn gamla Landsbankanum vegna pess að hann taldi sig eiga rétt á að skuldajafna láni í erlendri mynt sem hann hafði tekið hjá bankanum á móti afleiðusamningi sem hafði verið gerður til að eyða gengisáhættu af láninu. Landsbankinn bar fyrir sig að hann ætti ekki lánið lengur enda hefði pað verið flutt yfir til nýja bankans við yfirtöku skilanefndar. Afleiðusamningurinn var aftur á móti enn í gamla bankanum og hafði viðskiptavinurinn fengið kröfu sína sampykkta í búið enda var afleiðusamningurinn í hagnaði fyrir viðskiptavininn eftir fall krónunnar. Afleiðusamningurinn var sampykktur sem almenn krafa í búið en pegar á pessum tíma var vitað að pær kröfur myndu ekki innheimtast að fullu. Lánið hafði aftur á móti hækkað mikið vegna gengisfallsins og pví hafði viðskiptavinurinn töluverða hagsmuni af pví að fallist yrði á skuldajöfnun.

Í dómi héraðsdóms var vitnað til fyrrnefndar tilkynningar sem Fjármálaeftirlitið hafði sent frá sér í tilefni af uppskiptingu bankanna par sem segir: „Framsal kröfuréttinda samkvæmt pessari ákvörðun skal ekki svipta skuldara rétti til skuldajöfnuðar [svo] sem hann átti gagnvart fyrri kröfuhafa eða protabúi hans." Með vísan til pessarar tilkynningar taldi dómurinn að skuldarar mættu beina kröfu um skuldajöfnun til gamla bankans. Pá vísaði Porgils m.a. til 100. gr. laga um gjaldprotaskipti en dómurinn taldi að peir samningar, sem hagnaður hefði orðið af, hefðu verið gerðir innan priggja mánaða frá frestdegi.

Með lögum nr. 129/2008 um breytingu á lögum um fjármálafyrirtæki var ákveðið að frestdagur í peim fjármálafyrirtækjum, sem Fjármálaeftirlitið hafði pegar tekið yfir, yrði 15. nóvember 2008. Par sem síðasta framlenging samningsins hafði verið eftir 15 . ágúst 2008, p.e. innan priggja mánaða frá frestdegi, pá úrskurðaði Hæstiréttur að heimild til skuldajöfnunar á pessum grundvelli væri ekki til staðar. Viðskiptavinurinn vísaði einnig til greinar um skuldajöfnun afleiðusamninga í lögum um verðbréfaviðskipti varðandi skuldajöfnun á láninu og afleiðusamningnum. Héraðsdómur hafnaði pví að greinin gæti átt við í pessu máli par sem ekki var um skriflegan samning að ræða, p.e. lánið og afleiðusamningarnir væru ekki hluti af sama samningnum. Áður hafði viðskiptavinurinn haldið pví fram að lánasamningurinn væri í raun afleiðusamningur með gengi krónunnar sem afleidda breytu en dómurinn tók ekki undir pau rök. Dómurinn hafnaði pví skuldajöfnun á afleiðusamningnum og láninu; lagagreinin fjalli eingöngu um skuldajöfnun afleiðusamninga og pví geti lánasamningurinn ekki fallið undir pá grein. Hæstiréttur staðfesti síðan dóm héraðsdóms.

\subsubsection{Mál nr. 130/2011, Óskar Veturliði Sigurðsson gegn Landsbankanum hf.}

Deiluefni pessa máls var af sama toga og í máli Porgils gegn gamla bankanum (sjá 6.2.1). Óskar Veturliði Sigurðsson vildi fá lánasamningi skuldajafnað á móti gjaldmiðlaskiptasamningi. Gjaldmiðlaskiptasamningurinn var dagsettur pann 18. september 2008 og í honum var samið um skipti málsaðila á evrum fyrir dollara. Samningurinn var framlenging á eldri samningi en upphaflega höfðu aðilar gert með sér gjaldmiðlaskiptasamning pann 10. september 2007. Samningarnir voru yfirleitt gerðir til eins mánaðar í senn og síðan framlengdir og réðst gengið í hverjum samningi af gengi í eldri samningi að viðbættu álagi.

Hæstiréttur komst að peirri niðurstöðu að hver samningur væri sjálfstæður að efni og formi. Hver samningur hafði sérstakt númer og skuldbindingu vegna hvers samnings var að finna í texta hans án pess að vísað væri til eldri samninga. Hæstiréttur taldi pað einn- 
ig mikilvægt að í hverjum samningi kæmi fram skuldbinding um að hann skyldi efndur á gjaldaga á fyrir fram umsömdu gengi. Sú staðreynd að málsaðilar hefðu kosið að gera samningana upp með nýjum samningi breytti engu. Vegna pessa var pað mat Hæstaréttar að síðasti samningurinn, sem var gerður, hafi stofnast innan priggja mánaða frá frestdegi og pví var skuldajöfnunarkröfu Oskars hafnað. Í dómnum kemur einnig fram að óumdeilt sé að 100. gr. gjaldprotalaga gildi um pessar aðstæður og pví hefði ekkert verið pví til fyrirstöðu að skuldajafna samningnum á móti láninu ef samningurinn hefði verið gerður meira en premur mánuðum fyrir frestdag.

\subsubsection{Mál nr. 415/2011, Íslensk verðbréf hf. gegn Kauppingi banka hf.}

Deilt var um hvort nota mætti skuldabréf útgefin af Kauppingi í skuldajöfnun gagnvart kröfum Kauppings. Kaupping hafði handveð í bréfunum vegna afleiðusamninga Islenskra verðbréfa við Kaupping. Afleiðusamningarnir voru til varnar gengisáhættu af skuldabréfunum sem voru í evrum. Kaupping byggði á pví að par sem bréfin hefðu verið lögð að handveði pá væri ekki hægt að nota pau til skuldajöfnunar án sampykkis Kauppings. Pessu var Hæstiréttur ekki sammála og úrskurðaði að skuldajöfnunin væri heimil.

\subsubsection{Mál nr. 212/2012, Protabú Flugvals ehf. gegn Glitni hf.}

Deilt var um pað hvort Glitnir gæti lýst yfir skuldajöfnun vegna pess að bankinn hefði verið gjaldprota. Um pað segir í dómnum: „Skuldajöfnuður [svo] einnar kröfu við aðra samsvarar greiðslu. Enda pótt sá, sem vill nýta sér heimild sína til að greiða skuld með skuldajöfnuði, kunni að vera ófær um að greiða hana með reiðufé verður honum ekki meinað af peim sökum að efna skyldu sína með skuldajöfnuði.“ Pví taldi dómurinn ekki pörf á að taka afstöðu til pess hvort bankinn hefði verið gjaldprota. Í málinu höfðu aðilar gert með sér gjaldmiðlaskiptasamning og efndi hvorugur aðili samninginn á seinni gjalddaga hans.

Glitnir hafði umreiknað allar kröfur í íslenska mynt og beitt skuldajöfnun á kröfur bankans og kröfur Flugvals. Protabú Flugvals hélt pví fram að par sem Glitnir hefði ekki gjaldfellt samninginn skriflega, eins og kveðið er á um í SFF-skilmálunum, pá mætti hann ekki beita skuldajöfnun. Hæstiréttur staðfesti pá niðurstöðu héraðsdóms að par sem skuldajöfnun var ekki beitt fyrr en eftir að samningarnir voru fallnir í gjalddaga pá hefðu samningarnir gjaldfallið sjálfkrafa og Glitni ekki borið skylda til að senda sérstaka tilkynningu um gjaldfellinguna. Af pessum sökum var ekki fallist á að skuldajöfnunin hefði verið óheimil.

\subsubsection{Mál nr. 378/2014, Stapi lífeyrissjóđur gegn Kauppingi hf.}

Deilt var um pað hvort Kaupping hefði sýnt tómlæti við innheimtu á vaxtaskiptasamningi sem bankinn gerði við Stapa lífeyrissjóð. Vaxtaskiptasamningurinn var gerður til að verja sjóđinn fyrir gengisbreytingum á erlendu skuldabréfi sem sjóðurinn átti og giltu SFF-skilmálarnir um samninginn. Î honum kom fram að greiðslurnar skyldu skuldajafnast hvor á móti annarri en í raun var pað aldrei gert. Kaupping hafði annast allar greiðslur fyrir báða aðila. Í pví fólst að um leið og Stapi fékk greiðslur af erlenda bréfinu pá skuldfærði bankinn reikning sjóðsins fyrir allri evru-greiðslunni og lagði inn á eigin reikning. Á sama tíma greiddi bankinn fulla vaxtagreiðslu í íslenskum krónum inn á reikning sjóðsins í samræmi við samninginn.

Í málinu hélt Stapi pví fram að venja hefði skapast um að skuldajafna ekki greiðslum af samningnum og pví gæti bankinn ekki gert pað. Auk pess hefði bankinn sýnt tómlæti við innheimtu samningsins par sem fyrst hefði verið krafist efnda á honum í lok júní árið 2012. Рað var tæpum fjórum árum eftir að skilanefnd var skipuð yfir bankanum og báðir aðilar hættu að efna samninginn. Kaupping hélt pví aftur á móti fram að samningar hefðu staðið yfir við Landssamtök lífeyrissjóða, m.a. fyrir hönd Stapa, frá pví í desember 2008 um uppgjör á afleiðusamningum. 
Í dómi Hæstaréttar kom fram að breytt greiðslutilhögun hefði ekki breytt peim skuldbindingum sem aðilarnir gengust undir með samningnum og pví hefði Kauppingi verið heimilt að skuldajafna greiðslunum og umreikna pær í íslenskar krónur í samræmi við SFF-skilmálana. Jafnframt komst Hæstiréttur að peirri niðurstöðu að vegna heimildar annarra lífeyrissjóða til að ganga inn í samninga Landsamtaka lífeyrissjóða og peirra priggja lífeyrissjóða, sem fóru fyrir viðræðunum, pá hefði Kaupping mátt líta svo á að viðræður stæðu yfir. Ekki hefði verið rétt að aðhafast á meðan pær viðræður voru í gangi jafnvel pó að Stapi hefði ekki verið beinn aðili að samningnum.

\subsection{Samantekt}

Af framangreindu má ráða að Hæstiréttur lítur ekki á lánasamning og afleiðusamning, sem gerður er til varnar láni, sem sama gerninginn. Pví verður peim ekki skuldajafnað við gjaldprot nema í samræmi við almennar reglur gjaldprotalaga. Af pví leiðir að sé afleiðusamningur gerður pegar innan við prír mánuðir eru til frestdags pá er ekki heimilt að skuldajafna honum á móti kröfum protabúsins á hendur viðskiptavini. Jafnframt getur gjaldprota aðili lýst yfir skuldajöfnun og ekkert er pví til fyrirstöðu að nota eign, sem sett hefur verið að handveði, í skuldajöfnun gagnvart veðhafa.

\section{Viðbrögð bankanna við yfirtöku FME}

Fjármáleftirlitið tók yfir Landsbankann og Glitni pann 7. október 2008 og Kaupping pann 9. október og skipaði hverjum banka skilanefnd (Fjármálaeftirlitið, 2008a-c). Viðbrögð bankanna við yfirtöku Fjármálaeftirlitsins gagnvart viðskiptavinum, sem voru með opna afleiðusamninga, voru nokkuð mismunandi. Hér verður farið yfir viðbrögð hvers banka ásamt pví að skoða áhrif peirra á niðurstöður mála sem rötuðu fyrir dómstóla.

Fjármálaeftirlitið birti tilkynningu um ráđstöfun eigna og skulda Landsbankans pann 9. október. Par kom m.a. fram að réttindi og skyldur samkvæmt afleiðusamningum skyldu færast yfir til Nýja Landsbankans (Fjármálaeftirlitið, 2008d). Premur dögum síðar birti Fjármálaeftirlitið aðra tilkynningu par sem fyrri ákvörðun um að færa afleiðusamninga yfir í nýja bankann var dregin til baka. Samkvæmt tilkynningu eftirlitsins gat bankinn ekki staðið við pær skuldbindingar sem fólust í afleiðusamningunum. Par sagði orðrétt: „Verði ákvörðuninni ekki breytt er talið sýnt að Nýi Landsbanki Íslands hf. muni vanefna skuldbindingar samkvæmt peim samningum með ófyrirsjáanlegum afleiðingum“" (Fjármálaeftirlitið, 2008e). ${ }^{10}$

Í kjölfar pessarar tilkynningar Fjármálaeftirlitsins sendi skilanefnd Landsbankans tilkynningu til allra viðskiptavina sinna sem höfðu opnar afleiðustöður. Tilkynningin var pess efnis að vegna ákvörðunar Fjármálaeftirlitsins lægi fyrir að afleiðusamningum yrði lokað en án pess pó að tilgreina nánar hvenær peim yrði lokað.

Fjármálaeftirlitið sendi tilkynningu pann 14. október varðandi ráđstöfun eigna og skulda Glitnis par sem fram kemur að afleiðusamningar Glitnis flytjist ekki yfir til nýja bankans (Fjármálaeftirlitið, 2008f). Eins og Landsbankinn sendi Glitnir tilkynningu til viðskiptavina sinna varðandi stöðu afleiðusamninga en í bréfi Glitnis var orðalagið annað en í tilkynningu Landsbankans. Í tilkynningunni, sem Glitnir sendi viðskiptavinum sínum pann 27. október 2008, kemur fram að bankinn ynni að pví að loka og gera upp pá afleiðusamninga sem væru útistandandi. Viðskiptavinir voru jafnframt hvattir til að hafa samband við sinn tengilið í bankanum og finna leiðir til að ljúka samningunum og með uppgjöri eftir pví sem við ætti. Í bréfinu sagði einnig (Glitnir, tölvupóstur 27. október 2008):

Viðskiptamenn sem ekki kjósa að flýta uppgjöri í samkomulagi við Gamla Glitni verða krafðir um greiðslur í samræmi við viðkomandi samninga. Hins vegar liggur fyrir að samkvæmt ákvörðun skilanefndar verða kröf-

10 Ýtarlega umfjöllun um skiptingu eigna milli gömlu og nýju bankanna og álitamál henni tengd er að finna í 4. kafla bókar Ásgeirs Jónssonar og Hersis Sigurgeirssonar (2016), The Icelandic Financial Crisis. 
ur sem viðskiptamenn eiga á hendur Gamla Glitni að meginstefnu ekki greiddar að svo stöddu. Skuldajöfnuður kemur pá fyrst til greina pegar kröfur hafa fallið í gjalddaga, annað hvort samkvæmt efni samnings eða á grundvelli samkomulags um að flýta gjalddaga.

Verði bú Gamla Glitnis tekið til gjaldprotaskipta lokast allir afleiðusamningar sjálfkrafa og kröfur sem stofnast á grundvelli peirra falla í gjalddaga. Búið mun innheimta kröfur sem stofnast hafa á hendur viðskiptamönnum að fullu, en ótryggðar kröfur viðskiptamanna á hendur búinu verða greiddar út í samræmi við reglur gjald protaskiptalaga, eins og eignir búsins hrökkva til.

Fjármálaeftirlitið sendi tilkynningu varðandi ráðstöfun eigna og skulda Kauppings pann 22. október 2008 par sem kom fram að afleiður flyttust ekki yfir til nýja bankans (Fjármálaeftirlitið, 2008g). Kaupping virðist ekki hafa sent viðskiptavinum sínum tilkynningu pess efnis að afleiðusamningum skyldi lokað í kjölfar yfirtöku Fjármálaeftirlitsins, a.m.k. hafa ekki risið deilumál sem hafa ratað fyrir dómstóla varðandi efni slíkrar tilkynningar.

\subsection{Dómar Hæstaréttar}

\subsubsection{Mál nr. 320/2014, LBI hf. gegn Íslenskum verðbréfum hf.}

Landsbankinn og Íslensk verðbréf höfðu gert með sér gjaldmiðlaskiptasamning sem Landsbankinn krafðist fullra efnda á en samningurinn var með lokagjalddaga eftir að bankinn var tekinn yfir af Fjármálaeftirlitinu. Íslensk verðbréf héldu pví fram að bankinn gæti ekki krafist fullra efnda eftir að hann var búinn að lýsa pví yfir að hann myndi ekki standa við samninginn af sinni hálfu, sbr. fyrrnefnda tilkynningu um lokun afleiðusamninga, enda hefði gengispróunin geta breyst á pann veg að bankinn yrði í tapi af samningnum.

Að mati Hæstaréttar átti tilkynningin, sem Landsbankinn sendi viðskiptavinum sínum, sér enga stoð, hvorki í skilmálum bankans né í SFF-skilmálunum. Tilkynningin um lokun hefði ekki verið byggð á vanefnd af hálfu viðskiptavinar og pví leit dómurinn svo á að bankinn hefði með tilkynningunni fellt einhliða niður afleiðusamninga. Bankinn hefði lýst pví yfir að hann ætlaði ekki að standa við samningana af sinni hálfu og ætlaðist ekki til pess af hálfu viðskiptavina sinna. Par sem ekkert hefði verið í peim skilmálum, sem giltu um viðskiptasamband málsaðila sem heimilaði einhliða uppsögn á samningi án pess að komið hefði til vanefndar, pá réðist gildi tilkynningarinnar af viðbrögðum mótaðila við henni.

Í pessu tilfelli var pað í verkahring bankans að annast allar greiðslur vegna samningsins. Bankanum bar pví að sjá til pess að samningurinn skyldi efndur og hafði heimild til að nota reikninga viðskiptavinar til að efna hann. Bankinn framkvæmdi ekki greiðslur samkvæmt samningnum á gjalddögum og ástæða pess var ekki rakin til viðskiptavinarins. Pví leit rétturinn pannig á að Landsbankinn hefði vanefnt samninginn. Vegna athafnaleysis bankans á gjalddaga og tilkynningar, sem bankinn sendi, pá hefði viðskiptavinurinn mátt líta svo á að bankinn hefði einhliða fellt niður samninginn og að bankinn ætlaðist ekki til pess að viðskiptavinurinn myndi efna samninginn fyrir sitt leyti. Pví ætti bankinn ${ }^{11}$ „,ekki rétt til uppgjörs á skiptasamningnum sem tekur mið af pví að áfrýjandi verði eins settur og samningurinn hefði verið réttilega efndur af hálfu beggja aðila til lokadags".

Íslensk verðbréf höfðu sent Landsbankanum skuldajöfnunaryfirlýsingu par sem félagið krafðist pess að skuldajafna skuldabréfum bankans við afleiðusamninginn og taldi Hæstiréttur að Íslensk verðbréf hafi með pví viðurkennt að bankinn ætti gilda kröfu gegn félaginu og pví væri ekki hægt að sýkna félagið af kröfu Landsbankans. Pví var fallist á varakröfu Îslenskra verðbréfa og niðurstaða Hæstaréttar var sú að samningurinn skyldi gerður upp og uppgjör hans skyldi miða við 16. október 2008, pegar Landsbankinn sendi viðskiptavinum sínum tilkynninguna.

11 Bankinn var áfrýjandi í pessu máli. 


\subsubsection{Mál nr. 303/2013, LBI hf. gegn Norvik hf.}

Deilt var um uppgjör á fjórum gjaldmiðla- og vaxtaskiptasamningum sem gamli Landsbankinn og Norvik höfðu gert með sér. Pegar Landsbankinn sendi tilkynninguna varðandi lokun afleiðusamninga brást Norvik við með pví að senda bankanum beiðni um að samningarnir fengju að renna sitt skeið en beiðninni var ekki svarað af hálfu bankans. Í pessu máli var pað einnig í verkahring bankans að sjá um allar greiðslur en hann sinnti pví ekki eftir að honum var skipuð skilanefnd. Niðurstaða Hæstaréttar var að Norvik hafi mátt líta svo á að Landsbankinn hefði fellt einhliða niður samninginn með tilkynningu sinni og pví dæmdi Hæstiréttur að hann skyldi niður falla. Hæstiréttur leit m.a. til pess að langur tími hefði verið eftir af samningnum pegar Landsbankinn sendi tilkynninguna og ómögulegt hefði verið að sjá fyrir á peim tíma hvernig virði samningsins myndi próast.

\subsubsection{Mál nr. 245/2011, Landsbanki Íslands hf. gegn Ístaki hf.}

Mál petta varðaði tólf gjaldmiðlaskiptasamninga sem málsaðilar höfðu gert með sér. Pegar Ístak fékk tilkynninguna frá bankanum um lokun afleiðusamninga brást félagið við henni með pví að senda bankanum svar til baka í tölvupósti. Par sagði m.a. að félagið liti svo á að með bréfi sínu hefði skilanefndin lýst pví yfir að ekki yrði staðið við samningana. Prátt fyrir að engin heimild væri fyrir slíku pá sampykkti Ístak að fella samningana niður fyrir sitt leyti og sagði að félagið liti svo á að samningarnir féllu niður án frekari greiðslna. Pessu bréfi svaraði bankinn ekki og tók Hæstiréttur undir pað að Ístak hefði mátt túlka tilkynningu bankans og viðbrögð hans við tölvupóstinum á pennan veg. Pví var Ístak sýknað af kröfu Landsbankans um að standa við samningana.

\subsubsection{Mál nr. 288/2014, LBI hf. gegn protabúi Baugs Group hf.}

Deilt var um gildi fjórtán gjaldmiðlasamninga og fimm framvirkra hlutabréfasamninga sem Landsbankinn og Baugur höfðu gert með sér. Par sem lokagjalddagi gjaldmiðlasamninganna var áður en tilkynning Landsbankans um lokun afleiðusamninga var send var pað mat Hæstaréttar að tilkynningin hefði ekki haft áhrif á pá. Varðandi hlutabréfasamningana horfði Hæstiréttur til pess að viðskiptavinurinn hefði ekkert aðhafst pegar hann fékk bréfið frá bankanum. Pví leit dómurinn pannig á að samningurinn hefði ekki fallið niður enda bankanum óheimilt að fella hann einhliða niður án pess að til vanefndar hefði komið af hálfu viðskiptavinarins. Baugur hélt pví einnig fram að bankinn hefði ekki efnt sinn hluta samningsins, p.e. að afhenda bréfin, og pví hefði orðið vanefnd af hans hálfu. Hæstiréttur vísaði til niðurstöðu í máli nr. 630/2012 (sjá 2.2.2) par sem dómurinn hefði verið skýr varðandi pað að kaupanda bæri að hafa frumkvæði að pví að bjóða greiðslu og pá fyrst væri seljanda skylt að hafa eignina, sem átti að afhenda, tiltæka. Til pess var einnig horft í pessu máli. Pví var Baugur talinn hafa vanefnt samninginn pegar félagið bauð ekki greiðslu að fyrra bragði eða leitaði eftir pví að samningurinn skyldi efndur á lokagjalddaga.

\subsubsection{Mál nr. 647/2013, Straumborg ehf. gegn Glitni hf.}

Straumborg og Glitnir höfðu gert með sér framvirkan hlutabréfasamning um hlutabréf í Kauppingi hf. Samningurinn var upphaflega gerður í ársbyrjun 2008 og var svo framlengdur nokkrum sinnum án pess að til uppgjörs kæmi. Straumborg hélt pví m.a. fram að Glitnir hefði fellt niður samninginn með tilkynningu sinni um uppgjör afleiðusamninga.

Hæstiréttur staðfesti dóm héraðsdóms, sem sagði varðandi pessa málsvörn Straumborgar að Glitnir hefði ekki haft neina heimild til að fella samningana niður einhliða. Við mat á pví hvort viðskiptavinir mættu skilja tilkynningu bankans á pá leið að hann ætlaði ekki að efna samninginn sagði héraðsdómur að ekkert í yfirlýsingu Glitnis gæfi til kynna að viðskiptavinir hefðu mátt líta svo á að samningarnir væru niður fallnir. Pvert á móti kæmi pað fram að ef viðskiptavinir kysu ekki að flýta uppgjöri pá yrðu peir krafðir um greiðslur í samræmi við samninga. Kröfu Straumborgar var pví hafnað. 


\subsubsection{Mál nr. 216/2014, Havfisk ASA gegn Glitni hf.}

Norska fyrirtækið Havfisk rifti gjaldmiðlaskiptasamningi sem pað hafði gert við Glitni. Riftunin fór fram í desember 2008 eða eftir að bankinn hafði fengið heimild til greiðslustöðvunar. Samninginn hafði fyrirtækið gert við bankann samhliða skuldabréfaútboði í íslenskum krónum og átti samningurinn að losa fyrirtækið undan gengisáhættu. Heildaráhrif skuldabréfaútboðsins og samningsins saman voru sambærileg pví að fyrirtækið hefði gefið út skuldabréf í norskum krónum. Petta var grundvallarforsenda af hálfu viðskiptavinarins fyrir samningsgerðinni og hann hafði pví mikla hagsmuni af pví að samningurinn yrði efndur eftir efni sínu.

Í dómi Hæstaréttar kom fram að í lok október hefði verið fyrirsjáanleg vanefnd á grundvelli pess að ekki lék vafi á að bankinn væri orðinn ógjaldfær pegar hann var tekinn yfir. Auk pess var vísað í tilkynningu, sem hafði verið send til viðskiptavina daginn eftir að bankinn var tekinn yfir, par sem fram kom að engar kröfur erlendra aðila yrðu greiddar að svo stöddu. Petta var á grundvelli ákvæðis 5. gr. laga nr. 125/2008, neyðarlaganna, par sem segir að Fjármálaeftirlitið geti „takmarkað eða bannað ráðstöfun fjármuna og eigna fjármálafyrirtækis“. Vegna pess að fyrirsjáanleg vanefnd varð við yfirtöku Fjármálaeftirlitsins á bankanum var Havfisk heimilt að lýsa yfir riftun prátt fyrir pá vernd sem greiðslustöðvun veitir samkvæmt lögum. Hæstiréttur sagði einnig að tilkynning Havfisk um riftun hefði gefið Glitni tilefni til að gefa svör um pað hvort bankinn ætlaði að efna samninginn. Riftunartilkynningin væri sambærileg pví að viðskiptavinurinn krefðist svara við pví hvort bankinn hygðist efna samninginn í samræmi við 2. mgr. 91. gr. gjaldprotalaga. Samkvæmt peirri grein getur viðsemjandi beint pví til protabús hvort pað hyggist nýta sér heimild sem pað hefur til að taka við réttindum og skyldum samkvæmt samningnum sem sá aðili, sem fór í prot, er aðili að. Рað gerði Glitnir ekki og sýknaði Hæstiréttur Havfisk af kröfu Glitnis um að standa við samninginn.

\subsection{Samantekt}

Í kjölfar pess að Landsbankanum var skipuð skilanefnd af Fjármálaeftirlitinu sendi bankinn viðskiptavinum sínum tilkynningu varðandi uppgjör á afleiðusamningum. Orðalag tilkynningarinnar var nokkuð óljóst. Í henni kom m.a. fram að samningum viðskiptavina yrði lokað en ekki hvenær. Par sem orðalagið var óljóst og Landsbankanum var ekki heimilt að lýsa yfir einhliða lokun á samningunum pá hefur Hæstiréttur komist að peirri niðurstöðu að bankinn hafi tekið áhættu af pví að hver og einn viðtakandi leggi pann skilning í bréfið sem geti átt við aðstöðu viðkomandi. Pví hafi gildi tilkynningarinnar ráðist af viðbrögðum viðskiptavinar. Í málum par sem viðskiptavinur sendi svar við tilkynningunni par sem kom fram sampykki hans við niðurfellingunni, eða pað var í verkahring bankans að sjá um greiðslur af samningum fyrir hönd viðskiptavinar en pví var ekki sinnt af ástæðum sem verða ekki raktar til viðskiptavina, pá leit Hæstiréttur svo á að samningarnir hefðu fallið niður með tilkynningunni. İ máli par sem viðskiptavinur sýndi tómlæti við tilkynningunni var pað niðurstaða dómsins að samningarnir hefðu ekki fallið niður par sem bankanum var ekki heimilt að fella pá einhliða niður.

Tilkynning Glitnis til viðskipavina sinna um uppgjör afleiðusamninga í kjölfar pess að Fjármálaeftirlitið tók bankann yfir var ekki eins óljós og tilkynning Landsbankans. Hún var í raun boð til viðskiptavina um að semja um snemmbúna lokun samninganna en að öðrum kosti yrði innheimt í samræmi við pá. Hæstiréttur tók afstöðu til tilkynningarinnar í máli Straumborgar par sem kom skýrt fram að dómurinn taldi engan vafa á pví að viðskiptavinir máttu ekki skilja tilkynningu bankans á pann veg að hann væri einhliða að fella niður samningana. Рað kvað við nokkuð annan tón í máli erlends aðila, Havfisk. Par komst Hæstiréttur að peirri niðurstöðu að jafna mætti stöðu Glitnis við pað að bankinn væri ógjaldfær pegar hann var tekinn yfir af Fjármálaeftirlitinu. Hæstiréttur vísaði einnig til tilkynningar Glitnis um að engar kröfur erlendra aðila yrðu greiddar að svo stöddu. Pví hefði viðskiptavinurinn haft heimild til rifta samningnum í kjölfar pess. Einnig var litið 
svo á að riftunin jafngilti pví að Havfisk væri að krefjast svara um pað hvort bankinn ætlaði að efna samningana í samræmi við lög um gjaldprotaskipti. Par sem bankinn svaraði ekki riftunaryfirlýsingu félagsins var hún lögmæt að mati Hæstaréttar.

\section{8 Áhrif af yfirtöku Fjármálaeftirlitsins}

Mikilvægt er að gera sér grein fyrir pví hvenær gjaldfellingarheimildir virkjast í samningum. Pað getur verið mismunandi eftir pví hvaða skilmálar eiga við og um hvers konar fyrirtæki er að ræða. Allir helstu skilmálar afleiðusamninga, p.e. ISDA-skilmálar, SFF-skilmálarnir og skilmálar einstakra banka, kveða á um að við gjaldprot mótaðila gjaldfalli allir afleiðusamningar án sérstakrar tilkynningar par um. Samkvæmt lögum er félögum skylt að fara fram á gjaldprotaskipti pegar pau geta ekki lengur greitt skuldir sínar að fullu. Aðrar reglur gilda pó um fjármálafyrirtæki og samkvæmt lögum um fjármálafyrirtæki geta pau ekki farið fram á gjaldprotaskipti með sama hætti og önnur félög. Reynt hefur á pað í nokkrum málum hver staða bankanna hafi verið við yfirtöku Fjármálaeftirlitsins. Pví hefur m.a. verið haldið fram að staðan, sem bankarnir voru í, hafi jafngilt pví að gjaldprotameðferð væri hafin vegna peirra forsendna sem lágu að baki yfirtökunni.

\subsection{Helstu lagaákvæði}

Reglur um gjaldprotaskipti hefðbundinna félaga, annarra en fjármálafyrirtækja, er að finna í lögum nr. 21/1991 um gjaldprotaskipti. Samkvæmt lögunum hafa hefðbundin fyrirtæki almennt prjá valkosti lendi pau í greiðsluerfiðleikum: greiðslustöðvun, nauðasamninga og gjaldprotaskipti.

Greiðslustöðvun er tímabundið ástand sem veitir skuldara grið fyrir kröfuhöfum sínum á meðan hann reynir að styrkja rekstrargrundvöll sinn og geta kröfuhafar ekki gjaldfellt eða krafist greiðslu á kröfum sínum á meðan. Skuldari getur einnig óskað eftir heimild til nauðasamningsumleitana. Í pví felst að skuldari semji við kröfuhafa sína, yfirleitt um lengingu eða eftirgjöf skulda.

Nauðasamningur, sem sampykktur er af tilteknum meirihluta kröfuhafa og staðfestur af dómstólum, bindur alla almenna kröfuhafa. Á meðan heimild skuldara til að leita nauðasamnings stendur gilda sömu reglur og við greiðslustöðvun varðandi vernd skuldara gegn kröfuhöfum.

Skuldari, sem er bókhaldsskyldur, skal krefjast pess að vera tekinn til gjaldprotaskipta ef hann getur ekki staðið að fullu við gjaldfallnar skuldbindingar sínar gagnvart lánardrottnum og ekki er talið líklegt að greiðsluörðugleikar hans muni líða hjá innan skamms. Pegar dómari hefur fallist á gjaldprotabeiðni skuldara skipar hann skiptastjóra sem fer með forráð á búinu. Skiptastjóri birtir auglýsingu par sem hann óskar eftir pví að allir peir sem telji sig eiga kröfu á búið lýsi henni innan lögbundins frests og pegar kröfulýsingarfrestur er útrunninn tekur hann afstöðu til peirra krafna, sem hafa borist, og kröfuraðar peirra. Skiptastjóri sér um að ráđstafa eignum búsins til kröfuhafa í samræmi við kröfur peirra og kröfuröð (Lög um gjaldprotaskipti nr. 21/1991).

Reglur, sem gilda um slit fjármálafyrirtækja, er að finna í lögum nr. 161/2002 um fjármálafyrirtæki. Par kemur fram að fjármálafyrirtæki verði ekki tekin til gjaldprotaskipta eftir almennum reglum. Í stað pess að krefjast gjaldprotaskipta í fjárhags- eða rekstrarerfiðleikum skal stjórn fjármálafyrirtækis leita eftir pví við Fjármálaeftirlitið að pað fái yfirráð yfir fyrirtækinu. Fallist Fjármálaeftirlitið á beiðnina pá ber pví að víkja stjórn félagsins frá og skipa bráðabirgðastjórn. Á meðan bráðabirgðastjórnin er við völd í félaginu gilda sömu takmarkanir á heimildum kröfuhafa til að beita fullnustuaðgerðum eða öðrum pvingunarúrræðum og við greiðslustöðvun. Bráðabirgðastjórn getur farið fram á pað við héraðsdóm að fyrirtækið verði tekið til slita og skipar héraðsdómari pví pá slitastjórn. Reglur um skiptastjóra samkvæmt gjaldprotalögum gilda um slitastjórnina nema í peim tilfellum par sem annað er tekið fram í lögum um fjármálafyrirtæki (Lög nr. 161/2002 um fjármálafyrirtæki). 
Pegar Fjármálaeftirlitið tók yfir bankana í byrjun október 2008 skipaði pað svokallaða skilanefnd yfir bönkunum. Skilanefnd gegnir sama hlutverki og bráđabirgðastjórn í skilningi laga um fjármálafyrirtæki. Gömlu bankarnir fengu síðan heimild til greiðslustöðvunar pann 24. nóvember 2008.

\subsection{Dómar Hæstaréttar}

\subsubsection{Mál nr. 665/2013, Brim hf. gegn Kauppingi hf.}

Brim hafði gert vaxtaskiptasamning í japönskum jenum við Kaupping árið 2000 sem hafði verið efndur allt fram til október 2008. Brim byggði kröfu sína á pví að yfirtaka Fjármálaeftirlitsins á Kauppingi jafngilti gjaldproti. Ástæðan var að forsenda fyrir yfirtöku á bankanum samkvæmt lögum væri að félagið ætti í verulegum greiðsluerfiðleikum og bankinn hefði í raun verið gjaldprota ef ekki hefði komið til inngrips stjórnvalda. Pess vegna hefðu samningarnir gjaldfallið án sérstakrar tilkynningar í samræmi við SFF-skilmálana.

Héraðsdómur vísaði til tilkynningar, sem Fjármálaeftirlitið gaf út við yfirtökuna, par sem tekið var fram að engar skuldbindingar skyldu gjaldfalla við aðgerðina og engin vanefndarúrræði virkjast. Pví var ekki fallist á pað að yfirtakan á Kauppingi jafngilti gjaldproti í skilningi SFF-skilmálanna. Hæstiréttur staðfesti pessa niðurstöðu.

\subsubsection{Mál nr. 11/2014, Toppfiskur ehf. gegn Glitni hf.}

Toppfiskur og Glitnir höfðu gert með sér prettán gjaldmiðlasamninga sem voru á lokagjalddaga í október 2008 eftir að Glitnir hafði verið tekinn yfir. Toppfiskur taldi sig ekki purfa að efna samningana par sem peir hefðu fallið í gjalddaga við yfirtöku Glitnis sem jafna mætti við gjaldprot í skilningi SFF-skilmála og að greiðsluskylda félagsins hefði fallið niður. Með vísan til dóms í framangreindu máli nr. 665/2013 (sjá 8.2.1) og tilkynningar Fjármálaeftirlitsins um að ekki ætti að gefa út innköllun krafna komst Hæstiréttur аð peirri niðurstöðu аð við yfirtökuna hefði staða Glitnis ekki jafngilt gjaldproti og hafnaði pví peim rökum Toppfisks.

\subsubsection{Mál nr. 17/2013, Kaupping hf. gegn The Bank of Tokyo-Mitsubishi UFJ Ltd.}

Málsaðilar höfðu gert með sér skiptasamning um gjaldmiðla og átti seinni greiðsla samningsins að fara fram 9. október 2008 eða sama dag og Kaupping var tekið yfir. Japanski bankinn efndi samninginn fyrir sitt leyti um morguninn en engin greiðsla barst frá Kauppingi. Japanski bankinn fór fram á að krafa hans nyti hæsta forgangs við greiðslu úr protabúinu, p.e. samkvæmt 109. gr. gjaldprotalaga sem kveður á um eignir annarra í vörslu protabús, kallaðar sértökukröfur.

Í dómnum sagði Hæstiréttur að prátt fyrir að Kaupping hefði ekki verið tekið til slita fyrr en 22. apríl 2009 pá „voru öll málefni hans sett undir skilanefnd, sem skipuð var í skjóli opinbers valds og hlaut samkvæmt heiti sínu að hafa verið ætlað að leggja drög að aðgerðum til skuldaskila sóknaraðila." Af pessum sökum mátti líta svo á að gjaldprotaskipti væru hafin á Kauppingi um leið og skilanefndin tók bankann yfir.

\subsubsection{Mál nr. 175/2014, Deutsche Bank AG London gegn Kauppingi hf.}

Deutsche Bank hafði rift öllum afleiðusamningum við Kaupping á grundvelli ISDA-skilmálanna. Vísaði bankinn par til ákvæðis 5(a)(vii) að bankinn hefði verið ógjaldfær. Hæstiréttur tók undir pessa túlkun bankans með vísan til fyrri dóma sem höfðu fallið í Hæstarétti varðandi kröfuröðun, par á meðal máls nr. 17/2013 (sjá 8.2.3).

\subsubsection{Mál nr. 441/2011, Landsbanki Íslands hf. gegn Landsvaka hf.}

Deilt var um eignarhald á greiðslum af erlendu víkjandi skuldabréfi sem sjóður á vegum Landsvaka hafði keypt af Landsbankanum en bankinn sá um að koma greiðslum af skuldabréfinu til sjóðsins. Landsbankinn hafði upphaflega keypt bréfið af Deutsche Bank AG og 
var áfram eigandi bréfsins gagnvart pýska bankanum. Landsbankinn fékk pví greiðslur af bréfinu en átti að skila peim áfram til sjóðsins. Eftir að bankanum var skipuð skilanefnd fékk hann áfram greiðslur af bréfinu en hætti að skila peim til sjóðsins. Sjóðurinn fór pví fram á að krafa hans á hendur Landsbankanum yrði flokkuð sem forgangskrafa enda væri hann réttmætur eigandi greiðslna af bréfinu. Hæstiréttur féllst á petta og sagði:

Að pví virtu verður að líta svo á að á tímabilinu frá 7. október 2008 til 22. apríl 2009 hafi sóknaraðili verið í aðstöðu, sem leggja má að jöfnu við að hafin væru gjaldprotaskipti á búi hans að pví er varðar tilkall annarra á grundvelli eignarréttinda til peninga í vörslum hans.

\subsubsection{Mál nr. 77/2011, ALMC hf. gegn Landsbanka Íslands hf.}

Deilt var um pað hvort ALMC (áður Straumur-Burðarás Fjárfestingarbanki hf.) hefði verið heimilt að rifta afleiðusamningum við Landsbankann í kjölfar yfirtöku Fjármálaeftirlitsins á bankanum. Skilmálar Landsbankans og SFF-skilmálarnir giltu um viðskiptin en ef peir stönguðust á pá giltu skilmálar Landsbankans. Einnig var deilt um heimild til skuldajöfnunar. Krafa Landsbankans var annars vegar að riftunin yrði dæmd ógild og uppgjör samninganna yrði miðað við samningsbundna gjalddaga og hins vegar að samningunum yrði skuldajafnað. ALMC fór fram á að einungis yrði tekið tillit til peirra samninga par sem ALMC var í hagnaði og peim samningum yrði skuldajafnað á móti öðrum kröfum Landsbankans.

ALMC vísaði til pess að í skilmálum Landsbankans væri aðeins fjallað um rétt bankans við vanefnd gagnvart viðskiptavinunum en ekki væri gert ráð fyrir pví að bankinn gæti vanefnt samninginn. Af peim sökum taldi ALMC skilmála bankans ekki eiga við heldur SFF-skilmálana og vísaði pví til riftunarheimilda í peim. ALMC sagðist hafa upplýsingar um að samningum hefði verið rift við bankann sem lögðu greiðsluskyldu á hann. Pá vísaði ALMC einnig til ákvæðis í skilmálunum sem heimilar riftun ef mótaðila er skipt upp í tvö eða fleiri félög. Varðandi kröfu sína um að aðeins yrði tekið tillit til peirra samninga sem voru í hagnaði fyrir ALMC var vísað til pess að í SFF-skilmálunum segir að sá sem vanefnir samninginn eigi að bæta peim sem riftir honum allt tjón og miðað skuli við pann dag sem samningunum var rift. Раð sé aðeins ef samningar falla úr gildi með samkomulagi sem pað komi til pess að tekið sé tillit til taps pess sem riftir við útreikning á samningi.

Landsbankinn vísaði m.a. til 40. gr. laga nr. 108/2007 um skuldajöfnun afleiðusamninga en ALMC hélt pví fram að pað ákvæði gilti aðeins ef sérstaklega hefði verið samið um pað og pví breytti pað engu um SFF-skilmálana.

Héraðsdómur komst að peirri niðurstöðu að engin vanefnd hefði orðið af hálfu Landsbankans og par með hefði ALMC verið óheimilt að rifta samningunum. Í niðurstöðu dómsins segir:

Í tilvitnuðum ákvæðum er pannig ekkert fjallað um afskipti eða inngrip Fjármálaeftirlitsins í starfsemi samningsaðila, og verður með engu móti fallist á að peim aðgerðum verði jafnað við pau atvik sem sérstaklega eru talin par upp. Ekki verður heldur fallist á að ákvörðun Fjármálaeftirlitsins 9. október 2008 um að ráðstafa tilteknum eignum og skuldum Landsbanka Íslands hf. til Nýja Landsbanka Íslands hf. hafi jafngilt pví að sóknaraðila hafi í raun verið skipt í tvö félög.

Héraðsdómur komst pví að peirri niðurstöðu að prátt fyrir að eignum og skuldum Landsbankans hafi verið skipt í nýja og gamla bankann með hvor sína kennitölu að pá hafi bankanum ekki verið skipt í tvö félög.

Landsbankinn lagði fram upplýsingar, eftir áskorun ALMC fyrir Hæstarétti, sem sýndu að margir viðskiptavinir gjaldfelldu eða riftu samningum sínum í kjölfar yfirtöku Fjármálaeftirlitsins. Með vísan til greina 3.2 og 9.2 í SFF-skilmálunum komst Hæstiréttur að peirri niðurstöðu að ALMC hefði verið heimilt að rifta samningunum. Í greinunum 
kemur fram að ef samningar eru gjaldfelldir gagnvart samningsaðila vegna vanefndar pá sé mótaðila hans heimilt að rifta öllum samningum peirra á milli, skriflega. Petta ákvæði virðist pví ekki háð pví að aðrir samningar hafi verið gjaldfelldir af sama mótaðila vegna vanefndar gagnvart honum, heldur er nóg að samningsaðili hafi vanefnt samning gagnvart einhverjum mótaðila sem hafi leitt til gjaldfellingar. Í peim skilmálum Landsbankans, sem ALMC skrifaði undir, kom fram að skyldur samningsaðila skyldu jafnast hvor á móti annarri og einnig var vísað til greinar í lögum um verðbréfaviðskipti par sem fjallað er um skuldajöfnun. Hæstiréttur komst að peirri niðurstöðu að pessi grein skilmála Landsbankans gengi framar SFF-skilmálum. Pví var pað niðurstaða Hæstaréttar að ALMC hefði verið heimilt að rifta samningunum og peir skyldu gerðir upp m.v. pað en að kröfum samningsaðila skyldi skuldajafnað.

\subsection{Samantekt}

Nokkur munur hefur verið á niðurstöðu dómstóla um stöðu bankanna eftir yfirtöku Fjármálaeftirlitsins eftir pví hvaða skilmálar voru í gildi milli aðila. Hæstiréttur var skýr varðandi pá afstöðu sína að yfirtaka Fjármálaeftirlitsins á fjármálafyrirtækjum jafngildi ekki gjaldproti í skilningi SFF-skilmála um afleiðuviðskipti enda var pað tekið fram í tilkynningu Fjármálaeftirlitsins að engin vanefndarúrræði virkjuðust við aðgerðina. Prátt fyrir petta hefur Hæstiréttur tekið undir раð að skipun skilanefndar jafngildi pví að gjaldprotaskipti séu hafin varðandi sértökukröfur og afhendingu eigna vegna peirra, og einnig hefur hann fallist á að um vanefnd sé að ræða samkvæmt ISDA-skilmálum. Рað var pví mat Hæstaréttar að bankarnir ${ }^{12}$ hefðu verið í stöðu sem jafna mætti við að gjaldprotaskipti væru hafin m.t.t. sértökukrafna en ekki varðandi afleiðusamninga sem SFF-skilmálarnir og skilmálar einstakra banka giltu um.

\section{Niðurstöður og umræður}

Í pessari grein hefur verið farið yfir helstu ágreiningsmál varðandi uppgjör afleiðusamninga sem hafa komið til kasta íslenskra dómstóla. Markmiðið var að skýra betur hvaða reglur gilda um afleiðusamninga, hvenær mótaðili í samningum er gjaldprota og hvenær gjaldfellingarheimildir virkjast. Ágreiningsefnum var skipt gróflega sjö flokka. Hér á eftir má sjá helstu reglur sem höfundar telja að lesa megi úr peim dómum sem hafa verið reifaðir í pessari grein.

\subsection{Helstu niðurstöður}

\subsubsection{Heimildir til afleiðuviðskipta}

Ekkert í lögum bannar almennum fjárfestum að stunda afleiðuviðskipti og pví er öllum heimilt að stunda slík viðskipti. Pó eru mismunandi kröfur eftir flokkun viðskiptavina gerðar til fjármálafyrirtækja varðandi upplýsingaöflun um viðskiptavini og ráðgjöf til peirra.

Engar heimildir eru í lögum um verðbréfaviðskipti til að ógilda afleiðusamninga pó að fjármálafyrirtæki bregðist lagalegum skyldum sínum varðandi flokkun viðskiptavina, upplýsingaöflun um viðskiptavini eða ráðgjöf til peirra. Viðskiptavinir, sem telja sig hafa orðið fyrir tjóni vegna pess að fjármálafyrirtæki hafi ekki flokkað pá rétt eða ekki veitt nægjanlegar upplýsingar eða ráðgjöf, geta pó höfðað skaðabótamál.

Framvirkir samningar, a.m.k. um hlutabréf, eru ekki flóknir fjármálagerningar og pví ekki eins rík krafa gerð til fjármálafyrirtækja um upplýsingaöflun um viðskiptavini og ráðgjöf til peirra og ef um væri að ræða flókna fjármálagerninga.

Auknar skyldur um upplýsingaöflun fjármálafyrirtækja um viðskiptavini og ráðgjöf

12 Dómar, sem áđur voru reifaðir, sneru að Kauppingi og Landsbankanum en par sem Glitnir var í sömu stöðu má telja líklegt að sama gildi um hann. 
til peirra vegna nýrra laga um verðbréfaviðskipti frá árinu 2007, MiFID, eiga ekki við um eldri viðskiptavini nema viðskiptasambandið taki breytingum.

\subsubsection{Gengisviðmiðun við uppgjör gjaldmiðlasamninga}

Miða skal við gengisskráningu Seðlabanka Íslands pegar ekki er kveðið á um aðra gengisviðmiðun í afleiðusamningum. Рað breytir engu pó komi fram í skilmálum að miða skuli við gengi sem taki mið af markaðsaðstæðum ef ekki er tekið fram við hvaða gengisskráningu skuli miða.

\subsubsection{Reiknireglur við uppgjör}

Samkvæmt SFF-skilmálunum skulu samningar, sem falla niður vegna vanefndar, gerðir upp með núvirðingaraðferð. Ákvæðið í skilmálunum skal pó ekki nýtt til hagsbóta fyrir pann sem veldur vanefndinni. Ef sérstakir skilmálar gilda ekki um afleiðusamning gilda almennar reglur kröfuréttar um riftun sem segja að samningsaðilar skuli gerðir eins settir og samningurinn hafi aldrei verið gerður. Ekki pýðir að vísa til ákvæða SFF-skilmálanna sem almennrar venju sem hafi skapast við riftun eða uppgjör.

\subsubsection{Forsendubrestur}

Afleiðusamningar eru samningar um flutning áhættu frá einum aðila til annars og áhættuflutningurinn á sér stað um leið og samningurinn er gerður en ekki við uppgjör hans. Almennt er hagnaður eða tap af samningunum ekki takmörkuð við eitthvað hámark eða lágmark. Pví telst pað ekki forsendubrestur ef undirliggjandi eign verður verðlaus. Pá breytir engu pó kveðið hafi verið á um í samningum að undirliggjandi eign væri skráð í kauphöll en væri ekki hæf til skráningar á gjalddaga samnings.

Engin krafa er að afleiðusamningar séu skriflegir og pví er pað ekki forsenda afleiðusamninga. Engin slík krafa er í lögum og bæði SFF- og ISDA-skilmálar gera almennt ráð fyrir að samningar geti verið munnlegir, s.s. með símtali milli aðila, en skuli pó staðfestir skriflega. Í lögum um verðbréfaviðskipti er gerð krafa um að gert sé skriflegt samkomulag í upphafi viðskiptasambands banka og viðskiptavinar. Heimildir fjármálafyrirtækja til að gjaldfella samninga, ef peir berast ekki undirritaðir innan ákveðins frests, leggja engar skyldur á fjármálafyrirtæki og hafa engin áhrif á gildi samninganna ef heimildin er ekki nýtt.

\subsubsection{Skuldajöfnun}

Kröfu eða skuld skv. afleiðusamningi, sem gerður er til að verja áhættu af öðrum eignum eða skuldum, verður ekki skuldajafnað á móti peirri eign eða skuld sem hann var til varnar nema eftir almennum gjaldprotalögum. Við framlengingu afleiðusamnings með nýjum samningi, jafnvel pó að pað sé án eiginlegs uppgjörs, verður til nýr sjálfstæður samningur. Miða skal við dagsetningu pess samnings, sem var í gildi við gjaldprot mótaðila, pegar tekin er afstaða til pess hvort hann varð til fyrir frestdag. Gjaldprota aðila er heimilt að krefjast skuldajöfnunar.

\subsubsection{Viðbrögð bankanna við yfirtöku Fjármálaeftirlitsins}

Samningsaðilum er óheimilt að lýsa yfir einhliða lokun á samningum án pess að komið hafi til vanefndar af hálfu mótaðila. Tilkynning Landsbankans til viðskiptavina vegna opinna afleiðusamninga var óljós og túlka purfti pýðingu hennar út frá viðbrögðum hvers viðskiptavinar. Tilkynning Glitnis var skýrari og mátti aðeins túlka á einn veg.

\subsection{7 Áhrif af yfirtöku Fjármálaeftirlitsins}

Eftir yfirtöku Fjármálaeftirlitsins voru bankarnir í stöðu sem mátti jafna við upphaf gjaldprotaskipta m.t.t. sértökukrafna og skilyrða ISDA-skilmála en ekki hvað varðar skilyrði SFF-skilmálanna. Í slíkum málum hefur reynt á hversu víðtæk skilgreining á vanefnd var 
samkvæmt peim skilmálum sem giltu um samningana og var pað niðurstaða dómstóla að yfirtakan félli undir vanefnd skv. skilgreiningu ISDA-skilmála en ekki SFF-skilmála.

\subsection{Umræður}

Hæstaréttardómar, sem fallið hafa um uppgjör afleiðusamninga undanfarin ár, hafa skýrt réttarstöðu samningsaðila í afleiðusamningum og að einhverju leyti leitt í ljós brotalamir í framkvæmd samninga. Bankar og viðskiptavinir peirra purfa að huga að pví að breyta venjum og verklagi varðandi afleiðusamninga í samræmi við dómafordæmin.

Eitt skýrasta dæmið um petta er framlenging afleiðusamninga. Раð er viðtekin venja að gera afleiðusamninga til skamms tíma og framlengja pá pegar kemur að gjalddaga. Ef framkvæmdin við framlengingu afleiðusamnings er með peim hætti að nýr samningur er gerður í stað pess eldri pá geta mikilvæg réttindi samningsaðila glatast, t.d. réttur til skuldajöfnunar á móti öðrum kröfum eða skuldum aðila. Sumir bankar hafa pegar tekið upp pað verklag að við framlengingu afleiðusamnings er ekki gerður nýr samningur heldur er eldri samningi skilmálabreytt. Ekki hefur reynt á pað verklag fyrir dómi en ætla má að pá sé litið til upphafsdags upphaflega samningsins við ákvörðun á rétti til skuldajöfnunar.

Dómar Hæstaréttar sýna einnig að viðbrögð samningsaðila við vanefnd eða hugsanlegri vanefnd geta haft mikla pýðingu varðandi uppgjör afleiðusamninga. Gamli Landsbankinn sendi tilkynningu til viðskiptavina sinna um lokun afleiðusamninga sem reyndist mjög afdrifarík. Par sem orðalag tilkynningarinnar var óljóst var pað niðurstaða Hæstaréttar að hún skyldi túlkuð út frá viðbrögðum hvers viðskiptavinar við henni. Ef viðskiptavinir lýstu pví yfir að peir sampykktu lokunina án frekari greiðslna féll samningurinn niður. Ef viðskiptavinir svöruðu henni ekki pá gátu peir ekki borið pví við að bankinn hefði fellt einhliða niður samningana enda var pað ekki heimilt. Tilkynningin hafði veruleg áhrif á kröfur Landsbankans vegna afleiðusamninga og rétt viðbrögð viðskiptavina hans við tilkynningunni gátu haft veruleg jákvæð fjárhagsleg áhrif fyrir pá.

Sú niðurstaða Hæstaréttar að framvirkir samningar, a.m.k. um hlutabréf, teldust ekki flóknir fjármálagerningar er eftirtektarverð. Í rökstuðningi sínum benti Hæstiréttur réttilega á að lítill efnislegur munur væri á að gera framvirkan samning um að kaupa hlutabréf og að taka lán til kaupa á sömu hlutabréfum og pví er pessi niðurstaða rökrétt. Hún er pó í andstöðu við skilgreiningu Evrópusambandsins sem skilgreinir alla afleiðusamninga sem flókna fjármálagerninga.

Í dómum Hæstaréttar kom fram að bankarnir hefðu verið í stöðu sem mátti jafna við upphaf gjaldprotaskipta m.t.t. sértökukrafna og skilyrða ISDA-skilmála við yfirtöku Fjármálaeftirlitsins. Pað átti pó ekki við m.t.t. SFF-skilmálanna vegna pess að við yfirtöku Fjármálaeftirlitsins sendi pað tilkynningu pess efnis að samningarnir myndu ekki gjaldfalla. Раð er áhugavert að pessi tilkynning skyldi hafa haldið fyrir dómstólum og peir í raun tekið form tilkynningarinnar til greina umfram efni peirra aðgerða sem Fjármálaeftirlitið réðst í.

Athygli vekur að pó að íslenskir lífeyrissjóðir hafi verið meðal stærstu viðskiptavina bankanna í gjaldmiðlasamningum pá fór aðeins eitt ágreiningsmál peirra vegna afleiðusamninga fyrir Hæstarétt, mál Stapa lífeyrissjóðs gegn Kauppingi hf. nr. 378/2014 (sjá 6.2.5). Sem dæmi nam nafnvirði gjaldmiðlaskiptasamninga sex stærstu lífeyrissjóðanna um 900 milljónum evra við hrun (Rannsóknarnefnd Alpingis, 2010, 4. bindi bls. 117-134). Раð er pó ekki pannig að enginn ágreiningur hafi verið milli aðila um hvernig samningarnir skyldu gerðir upp heldur var að mestu leyti leyst úr honum með samningum milli aðila án aðkomu dómstóla (Landssamtök lífeyrissjóða, 2012; Lífeyrissjóður verkfræðinga, 2013). Samningarnir hafa ekki verið birtir opinberlega en af fréttum af peim að dæma bendir flest til að peir hafi verið lífeyrissjóðunum nokkuð hagfelldir miðað við niðurstöðu Hæstaréttar í sambærilegum málum. 


\section{Skrá yfir hæstaréttardóma}

ALMC hf. (Hörður F. Harðarson hrl.) gegn Landsbanka Íslands hf. (Jóhannes Sigurðsson hrl.). Hæstaréttardómur í máli nr. 77/2011. Pann 23. maí 2011.

Arnar Sigurðsson (Hjörleifur B. Kvaran hrl.) gegn SPB hf. (Ólafur Eiríksson hrl., Heiðar Örn Stefánsson hdl.). Hæstaréttardómur í máli nr. 253/2012. Pann 24. janúar 2013.

Bjarni Már Bjarnason (Guðmundur Ágústsson hrl.) gegn LBI hf. (Pétur Örn Sverrisson hrl.). Hæstaréttardómur í máli nr. 493/2013. Pann 23. september 2013.

Brim hf. (Grímur Sigurðsson hrl.) gegn LBI ehf. (Kristinn Bjarnason hrl.). Hæstaréttardómur í máli nr. 39/2016. Pann 6. október 2016.

Brim hf. (Porsteinn Einarsson hrl.) gegn Kauppingi hf. (Hlynur Halldórsson hrl.). Hæstaréttardómur í máli nr. 665/2013. Pann 27. mars 2014.

Byggingahúsið ehf. (Arnar Pór Stefánsson hrl.) gegn LBI hf. (Kristinn Bjarnason hrl.). Hæstaréttardómur í máli nr. 630/2012. Pann 2. maí 2013.

Byggingahúsið ehf. (Arnar Pór Stefánsson hrl.) gegn LBI hf. (Kristinn Bjarnason hrl.). Hæstaréttardómur í máli nr. 631/2012. Pann 2. maí 2013.

Deutsche Bank AG, London (Baldvin Björn Haraldsson hrl.) gegn Kauppingi hf. (Pröstur Ríkharðsson hrl.). Hæstaréttardómur í máli nr. 175/2014. Pann 24. mars 2014.

Eignarhaldsfélag RS ehf. (Hjörleifur B. Kvaran hrl.) gegn Glitni hf. (Ólafur Eiríksson hrl.). Hæstaréttardómur í máli nr. 112/2015. Pann 3. desember 2015.

Eignarhaldsfélag RS ehf. (Hjörleifur B. Kvaran hrl.) gegn SPB hf. (Ólafur Eiríksson hrl.). Hæstaréttardómur í máli nr. 158/2015. Pann 14. janúar 2016.

Einar Pétursson (Gísli Guðni Hall hrl.) gegn LBI hf. (Pétur Örn Sverrisson hrl.). Hæstaréttardómur í máli nr. 509/2013. Pann 16. janúar 2014.

Glitnir hf. (Andri Árnason hrl., Guðmundur Ingvi Sigurðsson hdl.) gegn Marel hf. (Gestur Jónsson hrl.). Hæstaréttardómur í máli nr. 421/2011. Pann 27. september 2012.

Glitnir hf. (Steinunn Hólm Guðbjartsdóttir hrl.) gegn Ottó Birni Ólafssyni (Arnar Pór Stefánsson hrl.). Hæstaréttardómur í máli nr. 222/2013. Pann 17. apríl 2013.

Gunnar Magnússon (Kristján Stefánsson hrl.) gegn Dróma hf. (enginn). Hæstaréttardómur í máli nr. 668/2014. Pann 27. október 2014.

Havfisk ASA (Eiríkur Elís Porláksson hrl.) gegn Glitni hf. (Aðalsteinn E. Jónasson hrl.). Hæstaréttardómur í máli nr. 216/2014. Pann 12. mars 2015.

Íslensk verðbréf hf. (Gestur Jónsson hrl.) gegn Kauppingi banka hf. (Stefán A. Svensson hrl.). Hæstaréttardómur í máli nr. 415/2011. Pann 18. október 2011.

Kaupping hf. (Anton B. Markússon hrl.) gegn The Bank of Tokyo-Mitsubishi UFJ Ltd. (Oddgeir Einarsson hrl.). Hæstaréttardómur í máli nr. 17/2013. Pann 25. febrúar 2013.

Kaupping hf. (Eiríkur Elís Porláksson hrl.) gegn Reykjavíkurborg (Kristbjörg Stephensen hrl.). Hæstaréttardómur í máli nr. 127/2014. Pann 6. nóvember 2014.

Landsbanki Íslands hf. (Jóhannes Sigurðsson hrl.) gegn Dynjanda ehf. (Ragnar Halldór Hall hrl.). Hæstaréttardómur í máli nr. 513/2011. Pann 22. mars 2012.

Landsbanki Íslands hf. (Jóhannes Sigurðsson hrl.) gegn Gift fjárfestingarfélagi ehf. (Anton B. Markússon hrl., Kristbjörg Stephensen hdl.). Hæstaréttardómur í máli nr. 561/2010. Pann 7. apríl 2011.

Landsbanki Îslands hf. (Jóhannes Sigurðsson hrl.) gegn Ístaki hf. (Einar Baldvin Axelsson hrl., Hjördís Halldórsdóttir hdl.). Hæstaréttardómur í máli nr. 245/2011. Pann 26. janúar 2012.

Landsbanki Íslands hf. (Pétur Örn Sverrisson hrl.) gegn Landsvaka hf. (Stefán Geir Pórisson hrl., Helga Melkorka Óttarsdóttir hdl.). Hæstaréttardómur í máli nr. 441/2011. Pann 28. nóvember 2011.

Landsbanki Íslands hf. (Kristinn Bjarnason hrl.) gegn Njálu ehf. (Sigurður G. Guðjónsson hrl.). Hæstaréttardómur í máli nr. 638/2010. Pann 24. janúar 2011.

LBI hf. (Kristinn Bjarnason hrl.) gegn Íslenskum verðbréfum hf. (Reimar Pétursson hrl.). Hæstaréttardómur í máli nr. 320/2014. Pann 15. janúar 2015.

LBI hf. (Kristinn Bjarnason hrl.) gegn Norvik hf. (Ragnar Tómas Árnason hrl.). Hæstaréttardómur í máli nr. 303/2013. Pann 17. október 2013.

LBI hf. (Kristinn Bjarnason hrl.) gegn protabúi Baugs Group hf. (Erlendur Gíslason hrl.). Hæstaréttardómur í máli nr. 288/2014. Pann 12. maí 2014.

NVN ehf. og Einar Örn Jónsson (Guðjón Ármann Jónsson hrl., Jón Ármann Guðjónsson hdl.) gegn Landsbanka Íslands hf. (Kristinn Bjarnason hrl., Guðbjarni Eggertsson hdl.). Hæstaréttardómur í máli nr. 184/2012. Pann 29. nóvember 2012.

Óskar Veturliði Sigurðsson (Ólafur Eiríksson hrl., Sigurður Snædal Júlíusson hdl.) gegn Landsbankanum hf. (Ólafur Haraldsson hrl., Guðmundur Ingvi Sigurðsson hdl.). Hæstaréttardómur í máli nr. 130/2011. Pann 19. janúar 2012.

Síminn hf. (Andri Árnason hrl.) gegn Glitni hf. (Aðalsteinn E. Jónasson hrl.). Hæstaréttardómur í máli nr. 773/2013. Pann 20. mars 2014.

SPB hf. (Ólafur Eiríksson hrl.) gegn Porgils Einari Ámundasyni (Björn Jóhannesson hrl.). Hæstaréttardómur í 
máli nr. 93/2011. Pann 24. nóvember 2011.

Stapi lífeyrissjóður (Hjörleifur B. Kvaran hrl.) gegn Kauppingi hf. (Hlynur Halldórsson hrl.) og gagnsök. Hæstaréttardómur í máli nr. 378/2014. Pann 26. febrúar 2015.

Straumborg ehf. (Ragnar Tómas Árnason hrl.) gegn Glitni hf. (Ólafur Haraldsson hrl.). Hæstaréttardómur í máli nr. 647/2013. Pann 3. apríl 2014.

Toppfiskur ehf. (Eiríkur Elís Porláksson hrl.) gegn Glitni hf. (Ólafur Eiríksson hrl.). Hæstaréttardómur í máli nr. 11/2014. Pann 11. september 2014.

Porgils Einar Ámundason (Björn Jóhannesson hrl.) gegn Landsbanka Íslands hf. (Pétur Örn Sverrisson hrl.). Hæstaréttardómur í máli nr. 15/2012. Pann 30. janúar 2012.

Protabú Flugvals ehf. (Svanhvít Yrsa Árnadóttir hdl.) gegn Glitni hf. (Steinunn Hólm Guðbjartsdóttir hrl.). Hæstaréttardómur í máli nr. 212/2012. Pann 26. apríl 2012.

\section{Heimildir}

Aðalsteinn E. Jónsson. (2011). Grunneðli afleiðna sem áhættugerninga: Í ljósi dóms Hæstaréttar í máli nr. 561/2010. Tímarit lögfræðinga, 61(1), 35-58.

Arion banki. (2012). Almennir markaðsskilmálar fyrir verðbréfaviðskipti milli Arion banka hf. og viðskiptavina bankans. Reykjavík: Höfundur.

Arion banki. (2008-2017). Ársskýrslur 2008-2017. Reykjavík: Höfundur.

Ásgeir Jónsson og Hersir Sigurgeirsson. (2016). The Icelandic financial crisis: A study into the world's smallest currency area and its recovery from total banking collapse. Basingstoke, Englandi: Palgrave Macmillan.

Bjarki H. Diego. (2001a). Afleiðusamningar. Lögmannablaðið, 7(1), 15-18.

Bjarki H. Diego. (2001b). Um samningsbundið uppgjör afleiðusamninga. Lögmannablaðið, 7(3), 13-15.

Committee of European Securities Regulators. (2009, 3. nóvember). MiFID complex and non-complex financial instruments for the purposes of the directive's appropriateness requirements (nr. CESR/09-559). París: Höfundur.

European Central Bank. (e.d.). Framework for the euro foreign exchange reference rates. Frankfurt am Main, Pýskalandi: European Central Bank.

Fjármálaeftirlitið. (2008). Upplýsingarit um MiFID fyrir neytendur: Að fjárfesta í fjármálaafurðum. Reykjavík: Höfundur.

Fjármálaeftirlitið. (2008a, 7. október). Ákvörđun Fjármálaeftirlitsins um skipan skilanefndar fyrir Glitni banka hf. Reykjavík: Höfundur.

Fjármálaeftirlitið. (2008b, 7. október). Ákvörðun Fjármálaeftirlitsins um skipan skilanefndar fyrir Landsbanka Íslands hf. Reykjavík: Höfundur.

Fjármálaeftirlitið. (2008c, 9. október). Ákvörðun Fjármálaeftirlitsins um skipan skilanefndar fyrir Kaupping banka hf. Reykjavík: Höfundur.

Fjármálaeftirlitið. (2008d, 9. október). Ákvörðun Fjármálaeftirlitsins um ráðstöfun eigna og skulda Landsbanka Íslands hf., kt. 540291-2259, til Nýja Landsbankans hf., kt. 471008-0280. Reykjavík: Höfundur.

Fjármálaeftirlitið. (2008e, 12. október). Ákvörðun Fjármálaeftirlitsins um breytingu á ákvörðun Fjármálaeftirlitsins pann 9. október 2008 um rádstöfun eigna og skulda Landsbanka Íslands hf., kt. 540291-2259, til Nýja Landsbankans hf., kt. 471008-0280. Reykjavík: Höfundur.

Fjármálaeftirlitið. (2008f, 14. október). Ákvörðun Fjármálaeftirlitsins um ráðstöfun eigna og skulda Glitnis banka hf., kt. 550500-3530, til Nýja Glitnis banka hf., kt. 491008-0160. Reykjavík: Höfundur.

Fjármálaeftirlitið. (2008g, 22. október). Ákvörðun Fjármálaeftirlitsins um ráðstöfun eigna og skulda Kauppings banka hf., kt. 560882-0419, til Nýja Kauppings banka hf., kt. 581008-0150. Reykjavík: Höfundur.

Glitnir. (2008). Annual Report 2007. Reykjavík: Höfundur.

International Swaps and Derivatives Association. (e.d.). About ISDA. Sótt af https://www.isda.org/about-isda/ International Swaps and Derivatives Association. (2002). ISDA master agreement. New York: Höfundur.

Íslandsbanki. (2008-2015). Ársskýrslur 2008-2015. Reykjavík: Höfundur.

Kaupthing Bank. (2008). Annual report 2007. Reykjavík: Höfundur

Landsbanki. (2008a). Annual report 2007. Reykjavík: Höfundur.

Landsbanki. (2008b). Condensed consolidated interim financial statements 1 January - 30 June 2008. Reykjavík: Höfundur.

Landsbankinn. (2008-2017). Ársreikningar 2008-2017. Reykjavík: Höfundur.

Landssamtök lífeyrissjóða. (2012, 4. maí). Samkomulag Glitnis og lífeyrissjóða um skuldauppgjör. Sótt af https://www.lifeyrismal.is/is/frettir/samkomulag-glitnis-og-lifeyrissjoda-um-skuldauppgjor

Lífsverk lífeyrissjóður. (2013, 11. janúar). Samkomulag Kauppings hf. og lífeyrissjóða um skuldauppgjör. Fréttir. Sótt af https://www.lifsverk.is/um-sjodinn/frettir/nr/92

Rannsóknarnefnd Alpingis. (2010). Aðdragandi og orsakir falls íslensku bankanna 2008 og tengdir atburðir. Reykjavík: Alpingi.

Samband íslenskra viðskiptabanka og Samband íslenskra sparisjóða. (1998). Framvirk gjaldmiðlaviðskipti og skiptasamningar. Reykjavík: Höfundar.

Seðlabanki Íslands. (2008a, 7. október). Unnið að lausn gjaldeyrisvanda [frétt nr. 34/2008]. Sótt af https://www. sedlabanki.is/utgefid-efni/frettir-og-tilkynningar/frettasafn/frett/2008/10/07/Unni\%C3\%B0-a\%C3\%B0- 
lausn-gjaldeyrisvanda/

Seðlabanki Íslands. (2008b, 8. október). Gjaldeyrismarkaður [frétt nr. 36/2008). Sótt af https://www.sedlabanki. is/utgefid-efni/frettir-og-tilkynningar/frettasafn/frett/2008/10/08/Gjaldeyrismarka\%C3\%B0ur-/

Seðlabanki Íslands. (2008c, 10. október). Tímabundin temprun á útflæði gjaldeyris [tilkynning Seðlabanka Íslands til innlánsstofnana]. Sótt af https://www.sedlabanki.is/lisalib/getfile.aspx?itemid=6491

Seðlabanki Íslands. (2008d, 28. nóvember). Frétt: Nýjar reglur um gjaldeyrismál [frétt nr. 46/2008]. Sótt af https://www.sedlabanki.is/utgefid-efni/frettir-og-tilkynningar/frettasafn/frett/2008/11/28/Fr\%C3\%A9ttN\%C3\%BDjar-reglur-um-gjaldeyrism\%C3\%A11-/ 